OPEN ACCESS

Edited by:

Richard Reed Veit,

College of Staten Island,

United States

Reviewed by:

Chris Elphick,

University of Connecticut,

United States

Sarah Ann Thompson,

Farallon Institute, United States

${ }^{*}$ Correspondence:

Robert William Henry III

rwhenry@ucsc.edu

${ }^{\dagger}$ Deceased

Specialty section:

This article was submitted to Behavioral and Evolutionary Ecology,

a section of the journal

Frontiers in Ecology and Evolution

Received: 21 October 2020 Accepted: 16 April 2021

Published: 25 May 2021

Citation:

Henry RW III, Shaffer SA

Antolos M, Félix-Lizárraga $M$, Foley DG, Hazen EL, Tremblay Y, Costa DP, Tershy BR and Croll DA (2021) Successful Long-Distance Breeding Range Expansion of a Top

Marine Predator.

Front. Ecol. Evol. 9:620103. doi: $10.3389 /$ fevo.2021.620103

\section{Successful Long-Distance Breeding Range Expansion of a Top Marine Predator}

\author{
Robert William Henry III ${ }^{1 *}$, Scott A. Shaffer ${ }^{2}$, Michelle Antolos ${ }^{1}$, Maria Félix-Lizárraga ${ }^{3}$, \\ David G. Foley ${ }^{4 t}$, Elliott L. Hazen ${ }^{4}$, Yann Tremblay ${ }^{5}$, Daniel P. Costa ${ }^{1}$, Bernie R. Tershy ${ }^{1}$ \\ and Donald A. Croll ${ }^{1}$ \\ 'Department of Ecology and Evolutionary Biology, University of California, Santa Cruz, Santa Cruz, CA, United States, ${ }^{2}$ San \\ Jose State University, Department of Biological Sciences, San Jose, CA, United States, ${ }^{3}$ Grupo de Ecología y Conservación \\ de Islas, Ensenada, Mexico, ${ }^{4}$ NOAA Southwest Fisheries Science Center, Environmental Research Division, Monterey, CA, \\ United States, ${ }^{5}$ UMR 248 MARBEC (IRD - IFREMER - CNRS - Univ. Montpellier), Sète, France
}

Little is known about the effects of large-scale breeding range expansions on the ecology of top marine predators. We examined the effects of a recent range expansion on the breeding and foraging ecology of Laysan albatrosses (Phoebastria immutabilis). Laysan albatrosses expanded from historical breeding colonies in the Central Pacific Ocean to the Eastern Pacific Ocean around central Baja California, Mexico, leading to a 4,000-km shift from colonies located adjacent to the productive transition zone in the Central Pacific to colonies embedded within the eastern boundary current upwelling system of the Eastern Pacific California Current. We use electronic tagging and remote sensing data to examine the consequences of this range expansion on atsea distribution, habitat use, foraging habitat characteristics, and foraging behavior at sea by comparing birds from historic and nascent colonies. We found the expansion resulted in distinct at-sea segregation and differential access to novel oceanographic habitats. Birds from the new Eastern Pacific colony on Guadalupe Island, Mexico have reduced ranges, foraging trip lengths and durations, and spend more time on the water compared to birds breeding in the Central Pacific on Tern Island, United States. Impacts of the range expansion to the post-breeding season were less pronounced where birds maintained some at-sea segregation but utilized similar habitat and environmental variables. These differences have likely benefited the Eastern Pacific colony which has significantly greater reproductive output and population growth rates. Laysan albatrosses have the plasticity to adapt to distinctly different oceanographic habitats and also provide insight on the potential consequences of range shifts to marine organisms.

Keywords: biogeography, colonization, North Pacific, climate change, albatross, top marine predator, range expansion

\section{INTRODUCTION}

Species distributions are changing rapidly (Hughes, 2000; Walther et al., 2002; Doney et al., 2011). While recent human activities and ecological change have contributed to the contraction of many species' ranges (Vitousek et al., 1997; Lambrinos, 2004; Thomas et al., 2006), other species have simultaneously shifted or expanded their ranges (Thomas and Lennon, 1999; Chen et al., 2011; 
Chan et al., 2019). Recent breeding range expansions have been documented for a diversity of terrestrial birds (Thomas and Lennon, 1999; Hitch and Leberg, 2007; Chen et al., 2011). Even though $65 \%$ of the earth's surface is pelagic marine habitat and most seabirds have broad foraging ranges, there are few examples of breeding range expansions among seabirds (Dunlap, 1988; Wynn et al., 2007).

Seabirds generally breed on remote islands, forage across wide areas of the ocean, exhibit high breeding site philopatry, and have low annual reproductive rates (Gaston, 2004). This makes them vulnerable to natural and anthropogenic stressors including incidental take by fisheries (Furness and Camphuysen, 1997; Brothers et al., 1999; 2003; Finkelstein et al., 2006; Wren et al., 2019), invasive species (Jones et al., 2008), habitat loss (Kavelaars et al., 2020), overexploitation (Meldgaard, 1988), pollution (Finkelstein et al., 2003), and climate change (Baker et al., 2006; Gremillet and Boulinier, 2009; Maxwell et al., 2013). Bottom-up processes, such as climate-driven changes in oceanographic processes can impact seabird species by shifting prime foraging locations, especially during the breeding period (Ainely and Divoky, 2001; Gremillet and Boulinier, 2009; Wolf et al., 2009; Thorne et al., 2016). Consequently, seabird populations may relocate to new islands where possible. If the current breeding location is remote with few other suitable breeding locations nearby, or populations are unable to adapt to regional oceanographic change, relocation to suitable breeding sites may require large shifts in breeding range.

Among seabirds, albatrosses exhibit extreme life-history patterns including delayed maturity, long lives, and low annual fecundity (Warham, 1990, 1996). Of all albatrosses, Laysan (Phoebastria immutabilis) and black-footed (Phoebastria nigripes) albatrosses are perhaps the most likely candidates for long-distance displacement of breeding colonies because they primarily nest on low-lying islands less than $2 \mathrm{~m}$ in elevation. Laysan albatrosses are more numerous with $70 \%$ of the global population nesting on five islands in the central North Pacific Ocean with a maximum elevation of 6 meters above sea-level (masl; Naughton et al., 2007; Arata et al., 2009). These colonies are adjacent to a singularly productive feature in the Central North Pacific region, the North Pacific Transition Zone (Polovina et al., 2001; Seki et al., 2004; Palacios et al., 2006; Kappes et al., 2010, 2015; Figure 1).

Within the last 30 years, Laysan albatrosses have expanded their range by $4,000-\mathrm{km}$ from historical breeding colonies in the Northwest Hawaiian Islands to breed on islands off Mexico in the California Current System of the Eastern Pacific Ocean (Pitman, 1985; Dunlap, 1988). This highly productive eastern boundary current is fed by a coastal upwelling front (Huyer, 1983; Checkley and Barth, 2009). Being a recent expansion, little is known about the foraging ranges and habits of Laysan albatrosses from this population. We had a unique opportunity to examine the consequences of largescale range shifts by comparing the foraging ecology of two Laysan albatross populations: the recently expanded Eastern Pacific population in Mexico and a population from one of the historic colonies in the Central Pacific on the Northwest Hawaiian Islands. This was accomplished by studying both colonies simultaneously using a combination of tracking and biologging methods to capture the behavior and distribution, and remotely sensed data to characterize the physical environment where albatrosses foraged. To explore the consequences of range expansion, our objectives were to compare: (1) at-sea distribution and behavior, (2) habitat use, (3) foraging habitat characteristics in relation to proximity to breeding colonies, and (4) differences in breeding performance. Finally, we explore the consequences of this range expansion on population growth. We found that these top marine predators used distinct oceanographic habitats through foraging plasticity and can provide insight on the types of range shifts that may occur as marine organisms respond to future climate and oceanographic change scenarios.

\section{MATERIALS AND METHODS}

\section{Historical Overview of Breeding Colonies}

Three species of albatrosses breed in the North Pacific: Laysan albatross, black-footed albatross, and short-tailed albatross (Phoebastria albatrus), with colonies historically located in the Western (off Japan) and Central North Pacific Ocean. In the late 1800s and early 1900s, overexploitation of albatross feathers, eggs, and guano resulted in significant declines and several local extirpations (Rice and Kenyon, 1962). Laysan albatrosses were extirpated in the Western Pacific and severely reduced in the Central Pacific by over 99\%. Historic numbers for Laysan albatrosses are unknown but were likely greater than present estimates, with one colony having over 2 million birds (Nutting, 1904). Laysan albatross population numbers have steadily increased from a low of approximately 18,000 to the present number of 600,000 breeding pairs, with growth having now plateaued (Arata et al., 2009). In the late 1970s and early 1980s Laysan albatrosses began to recolonize historically occupied sites in the Western Pacific on Mukokima, Japan and Wake Island, United States, and in the Central Pacific on the Main Hawaiian Islands (Chiba et al., 2007; Young, 2010). They also expanded their range to four Eastern Pacific sites off Mexico: Guadalupe, Alijos, Clarion, and San Benedicto Islands where prior breeding had not been documented (Pitman, 1985; Dunlap, 1988; Howell and Webb, 1990, 1992). Core Laysan albatross nesting colonies remain located in the Central Pacific Ocean (Arata et al., 2009; Figure 1).

We compared a population of Laysan albatrosses from Tern Island, French Frigate Shoals, in the Northwest Hawaiian Islands of the Central Pacific $\left(23.87^{\circ} \mathrm{N} 166.28^{\circ} \mathrm{W}\right)$ with a recently established population on Guadalupe Island, Mexico in the Eastern Pacific $\left(28.88^{\circ} \mathrm{N} 118.29^{\circ} \mathrm{W}\right)$ (Figure 1). Tern Island (10.5 ha) is part of a group of low-lying atolls ( $<6$ masl) centrally located within other Central Pacific colonies. Neighboring Whale-Skate Island recently eroded away resulting in the loss of breeding habitat for multiple species (Baker et al., 2006), including colony of Laysan Albatrosses (Young et al., 2009). Additional Laysan albatross nesting habitat was lost on East Island due to heavy erosion following a 2018 hurricane. In 2009, Tern Island had approximately 3,000 


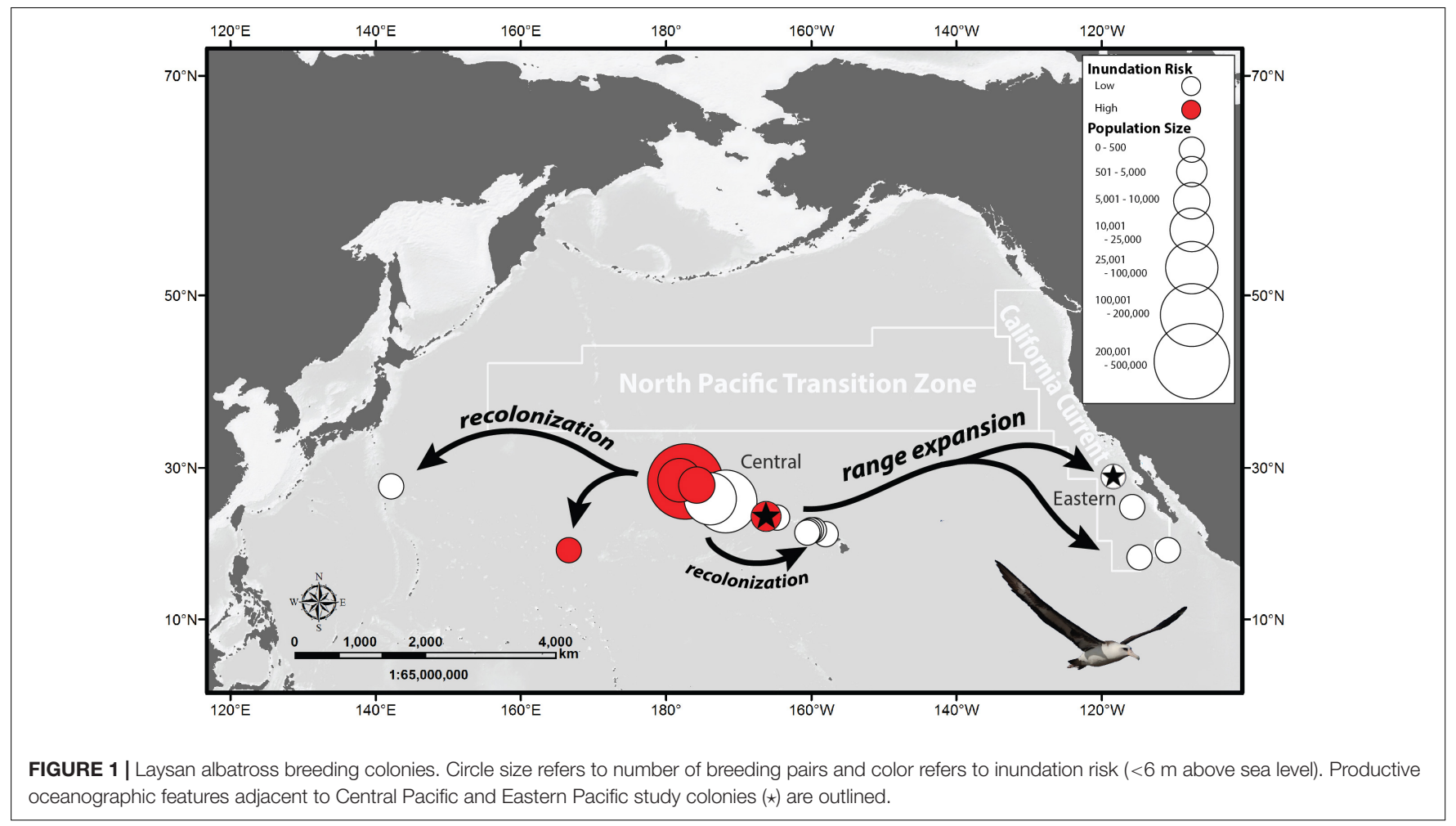

breeding pairs compared to Island with 457 breeding pairs. Guadalupe is larger (24,300 ha), higher (1,300 masl) and has a rapidly expanding population which grew to more than 1,200 breeding pairs by 2019 , despite having an introduced cat population that preyed upon the albatross for over 20 years (Hernández Montoya et al., 2014, 2019).

\section{Tagging}

We deployed two types of tags on breeding Laysan albatrosses December to June from 2002 through 2006 at Tern and Guadalupe Islands: $6 \mathrm{~g}$ archival global location sensing (GLS; LTD 2400, Lotek Wireless, St Johns, NF, Canada, GLS tags here after) and $35 \mathrm{~g}$ satellite platform terminal transmitters (PTTs; Pico-100, Microwave Telemetry, Columbia, MD, United States or Cricket, Wildlife Computers, Redmond, WA, United States). Deployments consisted of PTTs deployed in tandem with GLS tags (Tern $\mathrm{n}=69$, Guadalupe $\mathrm{n}=99$ ), PTT tags only (Tern $n=7$ ), or GLS tags only (Tern $n=50$, Guadalupe $n=65$ ). The combined mass of PTT and GLS tags was less than $2.5 \%$ of the $\sim 3.2 \mathrm{~kg}$ adult body mass, as required by our permits. A summary of tags recovered with viable data by colony and period is shown in Table 1.

Global location sensing tags provided long-term movement and temperature data and were attached to plastic leg bands via epoxy and cable ties. These tags captured multiple trips to sea and were deployed both within-breeding period (tags recovered during the same breeding period), inter-annually (tags recovered the following breeding period), and in some cases, recovered two years after deployments. They were programmed to record light level, pressure, and environmental temperature $\left( \pm 0.1^{\circ} \mathrm{C}\right)$ at intervals ranging from 4 to $540 \mathrm{~s}$ to accommodate memory capacity for different deployment lengths.

We attached PTTs to dorsal feathers using Tesa ${ }^{\circledR}$ 4651 waterproof adhesive tape (Hamburg, Germany) and programmed them to transmit every $90 \mathrm{~s}$, except for 31 deployments where tags were programmed to duty cycle (either $6: 18 ; 20: 4$; or $9: 15 \mathrm{~h}$ on:off) to maximize battery longevity. Satellite transmissions were downloaded via the Argos satellite system (Service Argos, Inc., Largo, MD, United States) using designated accuracy error classes (0-3, A and B).

\section{Location Data Post Processing}

Tracking data were analyzed with purpose-built routines created in MATLAB R2007b (The Mathworks, Natick, MA, United States). Location data from GLS tags were postprocessed following methods described in Shaffer et al. (2005) to yield two locations per day (local noon and midnight). PTT data were processed and analyzed following methods in

TABLE 1 | Summary of Laysan albatross tracking dataset, number of individuals tracked (number of trips included in the analysis) during breeding and post-breeding periods at Central Pacific and Eastern Pacific colonies.

\begin{tabular}{lcc}
\hline & Central & Eastern \\
\hline Incubation & $58(72)$ & $44(126)$ \\
Guarding & $39(41)$ & $37(49)$ \\
Chick-rearing & $26(157)$ & $38(222)$ \\
Post-breeding & $19(19)$ & $32(45)$ \\
Total & $104(289)$ & $76(442)$
\end{tabular}


Kappes et al. (2010). In order to use both types of location data comparably, the PTT data were interpolated using a Hermite spline following methods in Tremblay et al. (2006) and then subsampled to provide two locations per day (like the GLS data) sampled at local noon and midnight.

\section{Distribution and At-Sea Behavior}

Utilization distribution (UD) kernel estimates were used to determine spatial habitat distribution (Worton, 1989) for each combination of location/species/breeding period (e.g., incubation, chick-rearing). Laysan albatrosses are known to adjust their range according to ocean conditions and breeding period (Kappes et al., 2010, 2015), we treated each bird $\times$ breeding period $\times$ breeding year as the sample unit for kernel distribution and bootstrap analyses (described below). Utilization distributions $(95,50$, and 25\%) were calculated in MATLAB using methods in Kappes et al. (2010). For each trip, we estimated the maximum distance from the breeding colony, total distance traveled $(\mathrm{km})$, duration at sea (days), mean percent time on water (the ratio of sea surface to non-sea surface temperatures recorded by GLS tags), and mean distance to shore.

\section{Oceanographic Habitat}

Habitat was characterized by matching individual bird location with spatially and temporally referenced remotely sensed oceanographic data following methods described elsewhere (Shaffer et al., 2005, 2006; Kappes et al., 2010, 2015; Conners et al., 2015). We acknowledge that there may be some disconnect between what the birds perceive is good habitat versus what we were able to measure and describe with albatross distribution and remotely sensed data. This disconnect could be applied to virtually any seabird tracking study. Nevertheless, we feel that our study with large sample sizes provides a meaningful characterization of foraging by Laysan albatrosses.

Remotely sensed data were obtained from the NOAA's Environmental Research Division's Thematic Real-time Environmental Distributed Data Service (THREDDS) system. ${ }^{1}$ Oceanographic variables were selected based on established associations between albatross distribution and environmental covariates (Waugh et al., 1999; Hyrenbach et al., 2002; Suryan et al., 2006; Kappes et al., 2010; Wakefield et al., 2011; Thorne et al., 2016). For each albatross location at sea, we included variables for: wind speed $(\mathrm{m} / \mathrm{s})$, a blended 5-day sea surface temperature (SST) product $\left(\mathrm{SST},{ }^{\circ} \mathrm{C}\right)$, chlorophyll-a $(\mathrm{CHL}$, $\mathrm{mg} / \mathrm{m}^{3}$ ), eddy kinetic energy (EKE, J/kg), Ekman transport (WEKM, $\mathrm{m} / \mathrm{s}$ ), and sea surface height (SSH, m).

To characterize the habitats of the Central and Eastern Pacific Ocean, we created a composite for years 2003-2008 by averaging the means of extracted remotely sensed oceanographic data for each of the four breeding periods in $1^{\circ}$ longitude $\times 1^{\circ}$ latitude boxes across the North Pacific Ocean (Shaffer et al., 2005, 2006). These periods approximate annual Laysan albatross breeding phenology as follows: incubation (November 1-January 31 ), brooding (February 1-21); chick-rearing (February 22June 15); and post-breeding (June 16-October 31). Climatology

\footnotetext{
${ }^{1}$ http://oceanwatch.pfeg.noaa.gov/thredds/catalog.html
}

values contained in the 50\% UD contour were used to compare habitats available to each population and to define the standard extent of accessibility as a function of distance to colony. To characterize the environmental variables experienced by tracked albatrosses, we extracted, filtered, and selected remotely sensed oceanographic variables for each at-sea location following Henry (2011).

\section{Reproductive Metrics}

For each population, we determined annual breeding success (proportion of chicks fledged per eggs laid) and population counts (number of breeding pairs). Data for Tern Island was sourced from the US Fish and Wildlife Service (2003-2009) and published data (Arata et al., 2009; BirdLife International, 2021). Guadalupe Island data were compiled from the literature for years prior 2003 (Dunlap, 1988; Pitman, 1988; Gallo-Reynoso and Figuero-Carranza, 1996; Pitman and Ballance, 2002) and by the authors for 2003-2010. Chicks were considered fledged if observed in a healthy condition at the colony within a month of the average estimated fledging date. We compared the fledging success between colonies (2002-2010) and slopes of the natural log of the breeding population size (1992-2009).

\section{Statistical Analyses}

Statistical tests were performed in MATLAB and R (R Development Core Team, 2010). To compare ocean habitats surrounding each colony, we used the oceanographic climatology data bounded by the respective albatross 50\% utilization distributions for each colony. Analysis of variance was used to test the dependent environmental variable (contained within the $50 \%$ albatross utilization distribution) and covariate distance to colony for each $1^{\circ} \times 1^{\circ}$ grid cell with an interaction of breeding location (Central Pacific or Eastern Pacific).

Albatross habitats were modeled across wind speed, SST, CHL, EKE, WEKM, and SSH using the maximum entropy (MaxEnt version 3.3.3e) ${ }^{2}$ GUI-based approach (Phillips et al., 2006; Elith et al., 2010, 2011). We used resampling (10,000 iterations with replacement) to test the null hypothesis of no difference between Central Pacific and Eastern Pacific locations (Henry, 2011).

\section{RESULTS}

\section{Distribution}

The core distributions of both Laysan albatross populations had minimal overlap at sea during breeding and non-breeding with only $2.6 \%$ of $50 \%$ UD kernel overlap during the incubation period, $0 \%$ overlap during the chick brooding and rearing periods, and $23 \%$ overlap during the non-breeding period (Figure 2). The at-sea distribution of Central Pacific albatrosses was centered north of the breeding colony in the Central North Pacific, near the North Pacific Transition Zone. In contrast, Eastern Pacific albatrosses foraged mainly within the California Current System when breeding. Central Pacific birds moved north and west during the post-breeding period, residing along

\footnotetext{
${ }^{2}$ http://www.cs.princeton.edu/ schapire/maxent/
} 

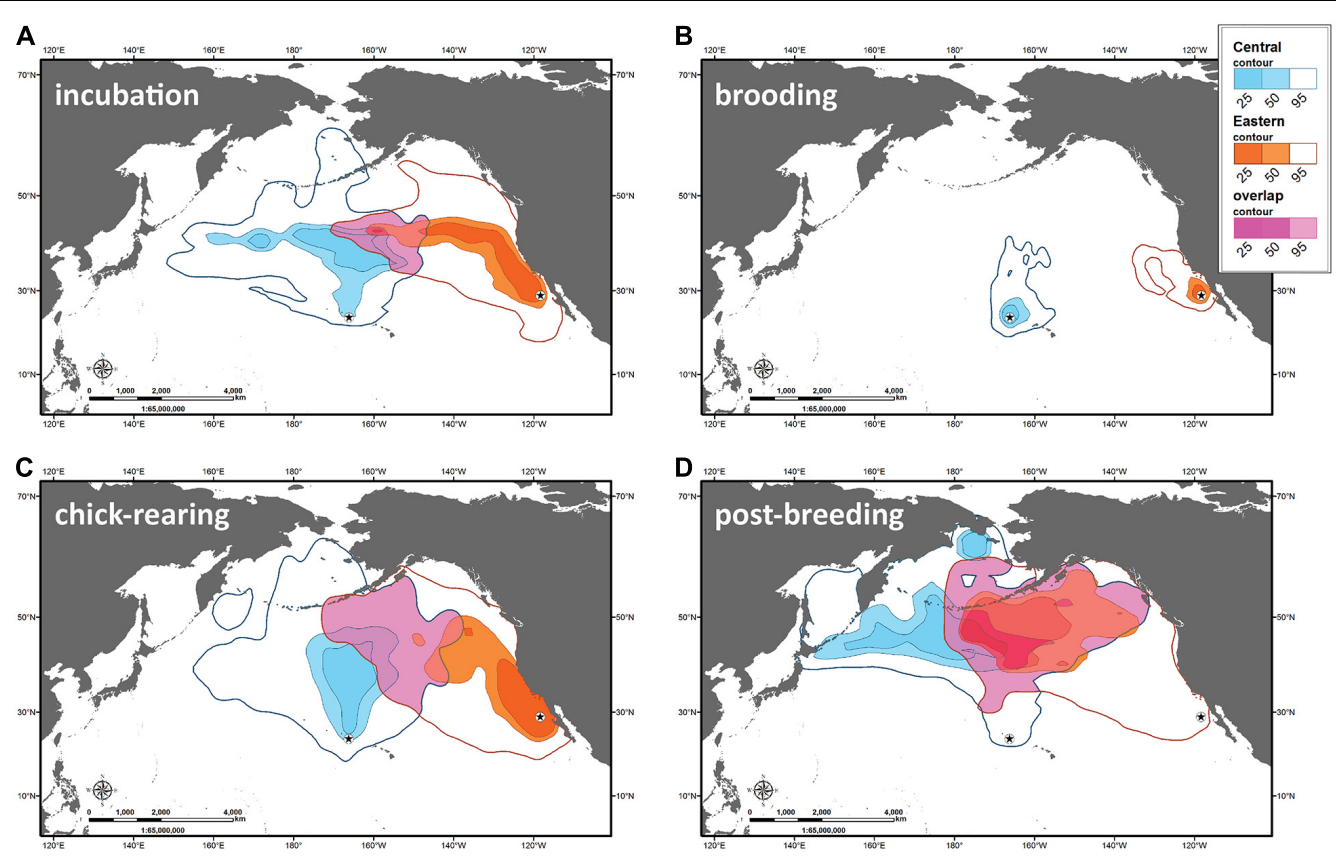

FIGURE 2 | At-sea distribution of Laysan albatrosses in the North Pacific Ocean. Contour plots from kernel density analyses of Central Pacific and Eastern Pacific Laysan albatross tracks during incubation, brooding, chick-rearing and post-breeding periods from 2003 to 2008 . Data are from merged GLS and PTT tracking datasets. Darker colors indicate areas of high residency with magenta colors showing overlap of the 25 , 50, and 95\% contours, respectively.

TABLE 2 | Behavior variables from Central Pacific and Eastern Pacific albatross tracks (mean and 95\% confidence intervals).

\begin{tabular}{|c|c|c|c|c|c|}
\hline Period & Location & Distance to colony (km) & Total distance traveled (km) & Duration (days) & Time on water (\%) \\
\hline \multirow[t]{3}{*}{ Incubation } & Central & $1646(1538,1774)$ & $6444(5455,7406)$ & $16.2(14,18.9)$ & $11.9(9.8,17.5)$ \\
\hline & Eastern & $861(601,1196)$ & $4633(3413,6530)$ & $12.1(9.5,15)$ & $16.8(12.2,22)$ \\
\hline & & $(P<0.001)$ & $(P=0.029)$ & $(P=0.011)$ & $(P=0.001)$ \\
\hline \multirow[t]{3}{*}{ Brooding } & Central & $164(125,210)$ & $821(548,1049)$ & $2.7(2.2,2.9)$ & $4(1.9,6.5)$ \\
\hline & Eastern & $93(58,129)$ & $554(433,722)$ & $2.4(2,2.8)$ & $13.4(7.2,20.8)$ \\
\hline & & $(P=0.005)$ & $(P=0.056)$ & $(P=0.19)$ & $(P=0.001)$ \\
\hline \multirow[t]{3}{*}{ Chick-rearing } & Central & $1550(1364,1792)$ & $7299(5615,8136)$ & $13.9(12.8,15.6)$ & $11.4(6.7,18.5)$ \\
\hline & Eastern & $458(319,601)$ & $3014(2227,3524)$ & $8(6.5,10)$ & $17.3(9.8,24.4)$ \\
\hline & & $(P<0.001)$ & $(P=0.004)$ & $(P=0.001)$ & $(P=0.123)$ \\
\hline \multirow[t]{3}{*}{ Post-breeding } & Central & $3090(2916,3358)$ & $42231(34879,45707)$ & $149.7(142,158)$ & $64.6(60,70.7)$ \\
\hline & Eastern & $3855(3673,4054)$ & $44950(42624,48219)$ & $161(158,165.5)$ & $71(68.3,73.2)$ \\
\hline & & $(P=0.002)$ & $(P=0.681)$ & $(P=0.014)$ & $(P=0.001)$ \\
\hline
\end{tabular}

the northern edge of the North Pacific Transition Zone, into the Western Subarctic Gyre with portions of the population residing along the Aleutian Chain and into polar waters. Eastern Pacific birds retained a more easterly distribution during this period, frequenting the northeastern North Pacific Transition Zone, Eastern Subarctic Gyre and along the inner and middle reaches of the Aleutian Chain.

\section{At-Sea Behavior}

During the incubation and chick-rearing periods, Central Pacific birds traveled significantly farther from the colony, covered greater distances, and spent more time at sea than Eastern Pacific birds (Table 2). Trip duration was not significantly different between sites during the brooding period where Central Pacific albatrosses remained closer to and spent less time away from their colony than did Eastern Pacific albatrosses. Central Pacific birds spent less time on the water during incubation, brooding, and post-breeding, but not during chick-rearing. The Eastern Pacific population remained relatively close to the coast of western North America, with mean distance to shore being 483, 268, and $283 \mathrm{~km}$ during incubation, brooding, and chick-rearing, respectively. 


\section{Habitat Preferences}

Birds from each colony used distinctly different habitats during breeding and post-breeding (Table 3). SST, wind speed, and CHL were the most important habitat predictors (Table 3). The relative importance of these and other variables changes with breeding location and period. The values of multi-year composites of habitat predictors change with distance from the colony (Figures 3-5).

Central Pacific albatross at-sea distribution was most closely associated with $\mathrm{CHL}$ values during incubation and chickrearing. Their presence was correlated with the Transition Zone Chlorophyll Front located at the $0.2 \mathrm{mg} / \mathrm{m}^{3}$ surface CHL contour (Polovina et al., 2001). In contrast, during the same periods Eastern Pacific birds associated with SST values such as those found in the edges of filaments and eddies of the coastal upwelling front of the California Current System (Brink and Cowles, 1991; Strub et al., 1991; Castelao et al., 2006).

During incubation, both CHL and SST had significantly different interaction effects with colony location $\left(F_{3,627}=843\right.$, $P<0.001$ and $F_{3,627}=79.7, P<0.001$; Figures 4A, 5A). Wind speed did not show a significant interaction effect and had a similar positive relationship with distance to the colony $\left(F_{3,627}=1808, P=0.12\right.$; Figure 3A $)$. However, wind speeds were greater surrounding the Central Pacific colony $\left(F_{3,627}=1808\right.$, $P<0.001)$. Central Pacific birds accessed regions of higher wind speed, cooler SSTs, and higher CHL as they ranged farther from the colony (Table 3 and Figures 3A, 4A, 5A). Eastern Pacific birds were also associated with cooler SSTs, encountering cooler waters as they traveled further from the colony (Table 3 and Figure 4A). They experienced lower wind speeds and accessed regions with a

TABLE 3 | Summary of MaxEnt model results for Central Pacific and Eastern Pacific colonies.

\begin{tabular}{|c|c|c|c|c|c|c|c|c|c|}
\hline \multirow[b]{2}{*}{ incubation } & \multicolumn{4}{|c|}{ Central } & & \multicolumn{3}{|c|}{ Eastern } & \multirow[b]{2}{*}{ Relationship } \\
\hline & Variable & $\begin{array}{c}\text { Percent } \\
\text { contribution }\end{array}$ & $\begin{array}{l}\text { Permutation } \\
\text { importance }\end{array}$ & Relationship & & Variable & $\begin{array}{c}\text { Percent } \\
\text { contribution }\end{array}$ & $\begin{array}{l}\text { Permutation } \\
\text { importance }\end{array}$ & \\
\hline \multirow[t]{4}{*}{$A \cup C=0.783$} & $\mathrm{CHL}$ & 37.1 & 42.9 & - & $A \cup C=0.829$ & SST & 28.3 & 32.4 & - \\
\hline & Windsp & 32 & 18.8 & +++ & & Windsp & 24.3 & 17.4 & - \\
\hline & SST & 19.1 & 26.5 & 0 & & $\mathrm{CHL}$ & 20.5 & 21.5 & - \\
\hline & WEKM & 1.5 & 2.6 & & & SSH & 3.3 & 6.4 & \\
\hline
\end{tabular}

brooding

$\begin{array}{ccc}\text { SST } & \mathbf{8 9 . 1} & \mathbf{8 0 . 3} \\ \text { EKE } & 3.4 & 2.6 \\ \text { WEKM } & 2.8 & 2.9 \\ \text { SSH } & 2.8 & 2.5 \\ \text { CHL } & 1.7 & 9.2 \\ \text { Windsp } & 0.3 & 2.6\end{array}$

$+++\quad$ AUC $=0.777$

SST

EKE

$\mathrm{CHL}$

WEKM

SSH

Windsp

$\mathbf{9 5 . 3}$
1.5
1
1
0.6
0.5

71.7
2.9
9.9
0
10.6
4.9

chick-rearing

AUC $=0.812$

$\begin{array}{cc}\text { CHL } & \mathbf{3 2 . 6} \\ \text { EKE } & \mathbf{2 0 . 2} \\ \text { Windsp } & \mathbf{1 9 . 2} \\ \text { SST } & \mathbf{1 4 . 3} \\ \text { WEKM } & 7 \\ \text { SSH } & 6.7\end{array}$

$\mathbf{5 6}$
$\mathbf{8 . 2}$
$\mathbf{1 . 6}$
$\mathbf{2 1 . 8}$
9.2
3.1

0
+++
+
0

SST
SSH
CHL
Windsp
EKE
WEKM

$\mathbf{5 8 . 4}$
$\mathbf{1 5 . 1}$
$\mathbf{1 3 . 6}$
6.4
3.4
3.1

$\begin{array}{cc}\mathbf{4 3 . 1} & \mathbf{0} \\ \mathbf{1 3 . 6} & \mathbf{0} \\ \mathbf{2 0 . 2} & - \\ 8.2 & \\ 4.4 & \\ 10.4 & \end{array}$

post-breeding

AUC $=0.798$

$\begin{array}{ccc}\text { SST } & \mathbf{4 5 . 3} & \mathbf{3 1 . 5} \\ \text { Windsp } & \mathbf{2 6 . 2} & \mathbf{1 5 . 8} \\ \text { SSH } & \mathbf{1 0 . 3} & \mathbf{1 8 . 5} \\ \text { WEKM } & \mathbf{9 . 8} & \mathbf{2 8 . 5} \\ \text { EKE } & 7 & 5.3 \\ \text { CHL } & 1.4 & 0.3\end{array}$

$\begin{array}{cl}+++ & \text { AUC }=0.855 \\ - & \\ - & \\ \mathbf{0} & \end{array}$

SSH
CHL
Windsp
SST
EKE
WEKM

42
21.1
16.5
15.1
2.9
2.4

$\begin{array}{cc}47.4 & 0 \\ 31.4 & - \\ 6.3 & - \\ 10.4 & - \\ 3.8 & \\ 0.8 & \end{array}$

Area under the receiver operating characteristic curve (AUC - a measure of explanatory power) and percent contribution of each environmental variable to the model are listed for each breeding period. Environmental variables include wind speed (Windsp), sea surface temperature (SST), chlorophyll-a (CHL), eddy kinetic energy (EKE), Ekman vertical transport (WEKM), and sea surface height (SSH). Important predictive variables are shown in bold. The association and strength between albatross presence and environmental variables are indicated with,+ 0 , and - (positive, neutral, and negative). 


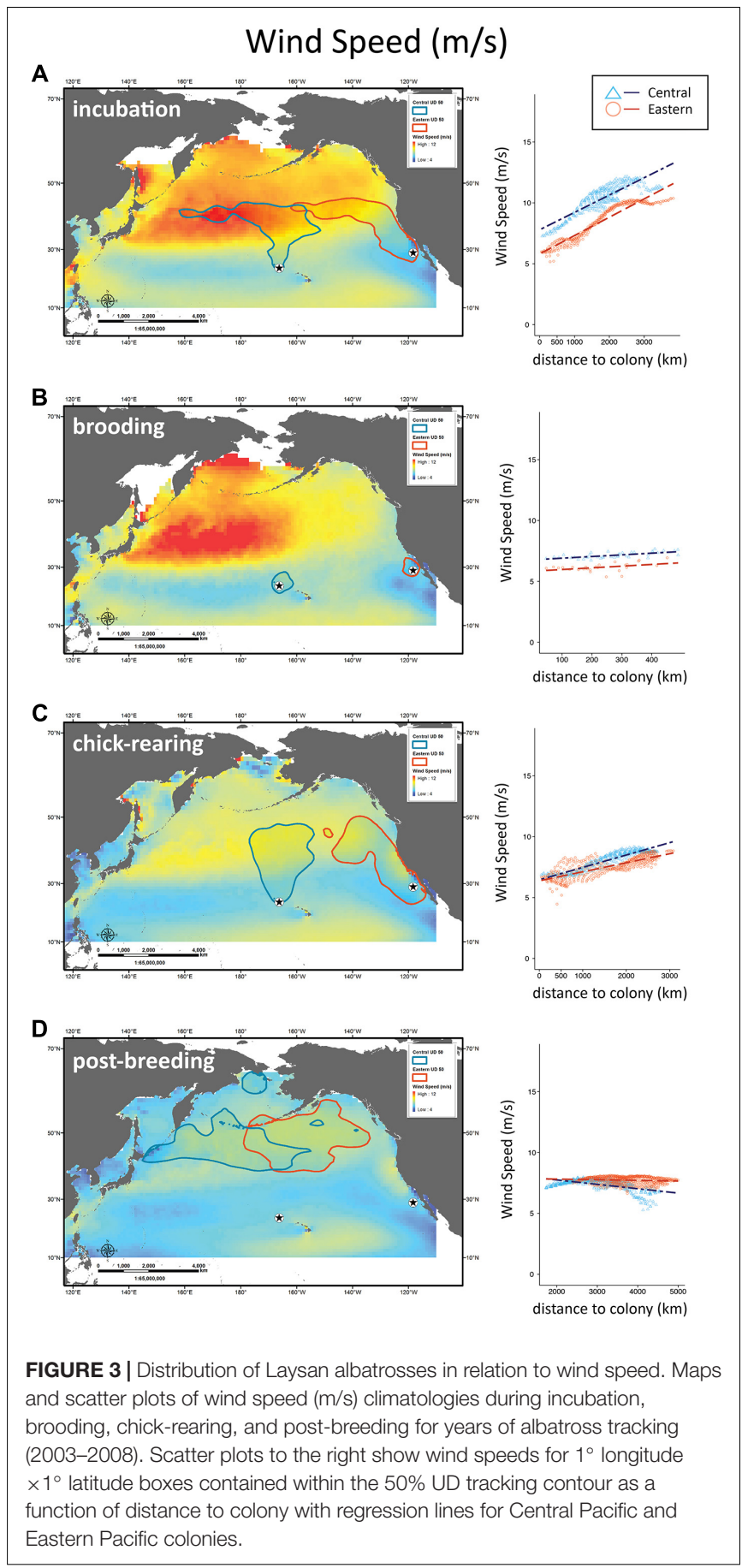

broader range of CHL values than Central Pacific birds (Table 3 and Figures 3A, 5A, 6A).

During brooding SST was the sole predictive variable for both populations, with Central Pacific albatrosses utilizing warmer waters compared to Eastern Pacific birds (Table 3). Brooding adults are highly constrained by trip duration and distance from the breeding colony (Figure 2). Wind speed and SST had similar relationships $\left(F_{3,62}=143, P=0.98\right.$ and $F_{3,62}=440$, $P=0.96)$ but were both significantly greater surrounding the

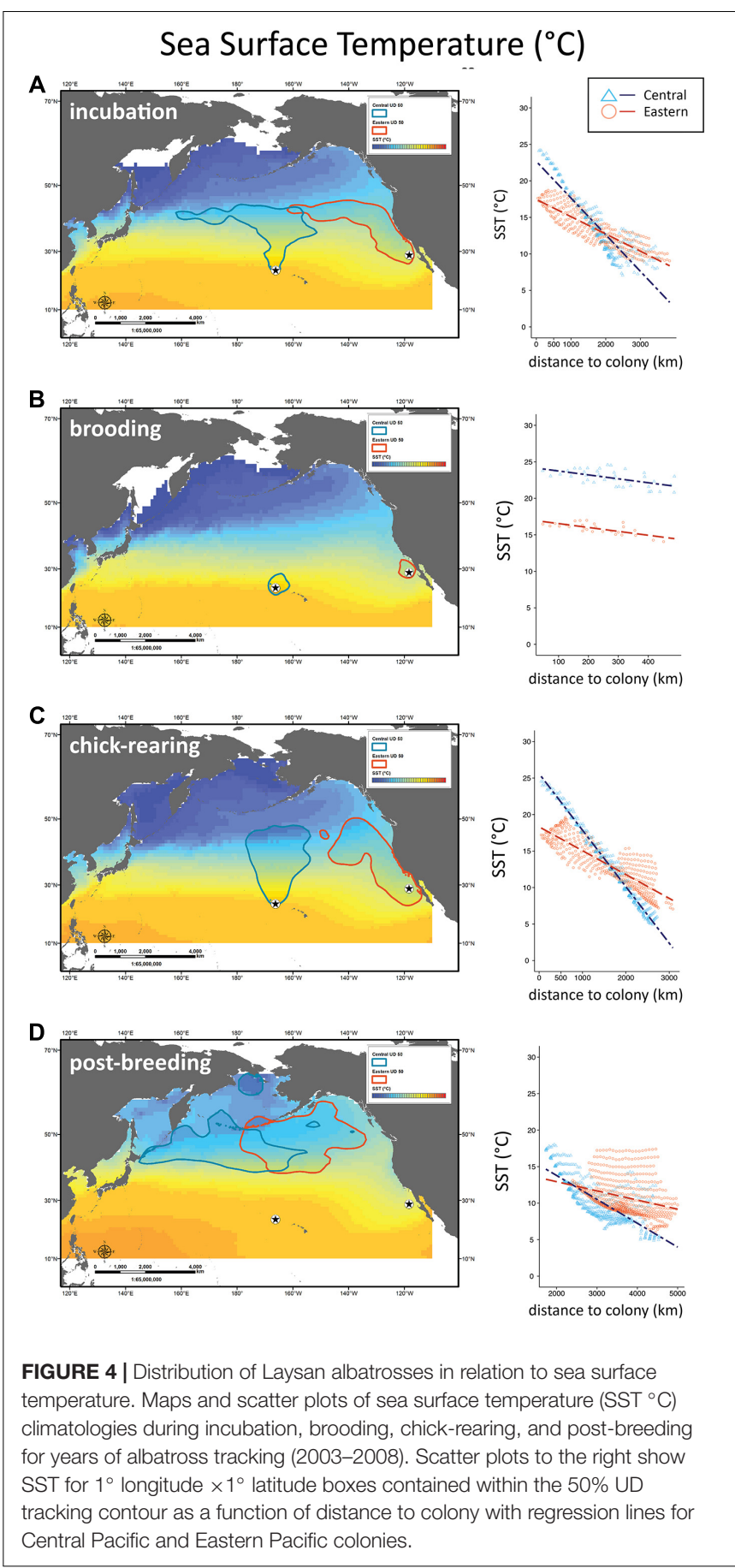

Central Pacific colony $\left(F_{2,63}=143, P<0.001\right.$ and $F_{2,63}=440$, $P<0.001$ ); CHL had different relationships with distance to each colony and was greater in waters near the Eastern Pacific colony $\left(F_{3,62}=22.4, P<0.001\right.$; Figures 3B, 4B, 5B $)$.

During chick-rearing both Central and Eastern Pacific birds accessed regions of similar wind speeds and encountered higher wind speeds as they ranged farther from the colony. Adults can range more widely at this time because chicks are larger and are able remain alone at the colony for weeks. The relationship 


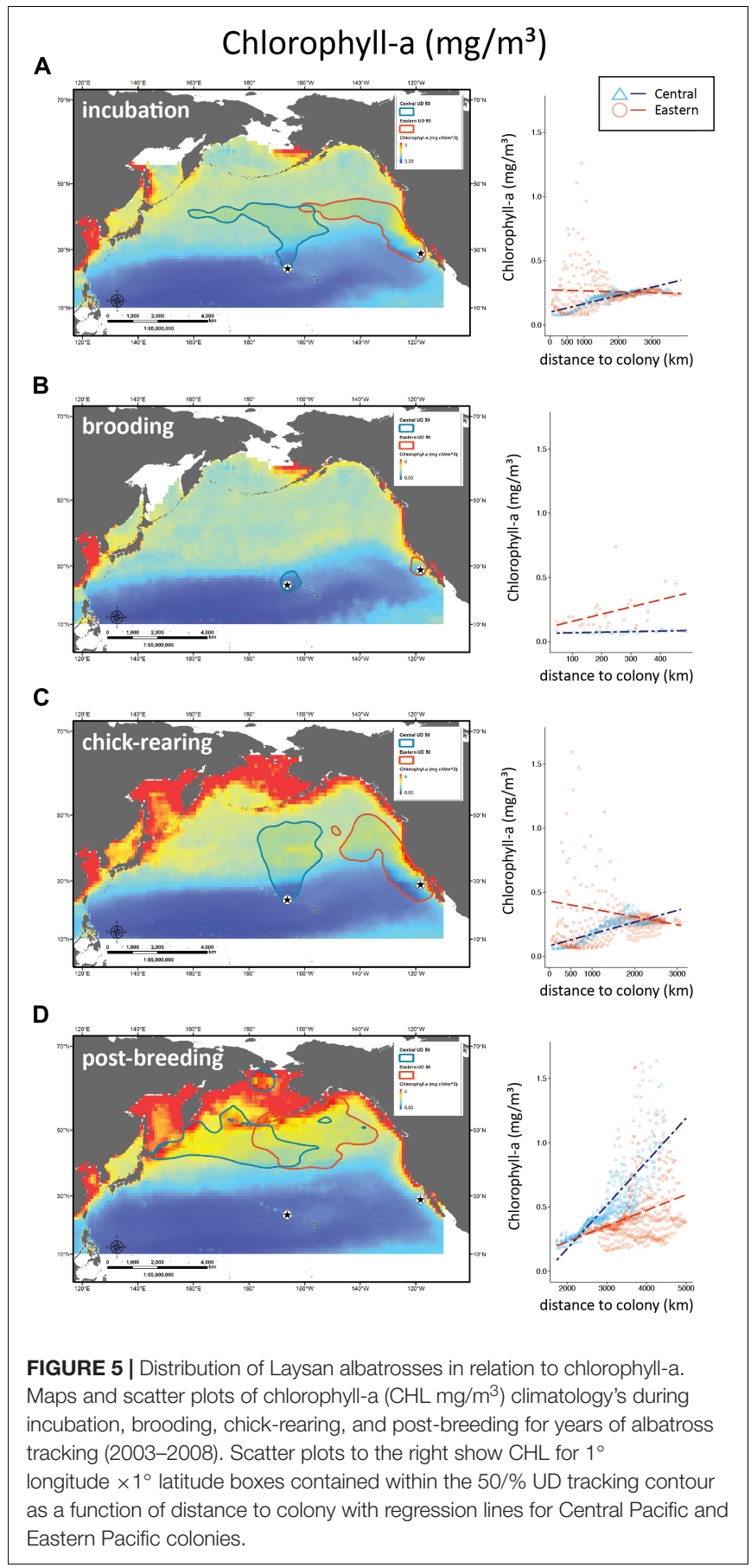

between wind and distance to colony was steeper for the Central Pacific colony $\left(F_{3,754}=802, P<0.001\right.$; Figure 3C). Eastern Pacific birds had access to regions of lower SST and higher CHL in close proximity to the colony while Central Pacific birds had to travel farther to access regions of low temperatures and higher productivity $\left(F_{3,754}=802, P<0.001\right.$ and $F_{3,754}=8.92$, $P<0.001$; Figures 4C, 5C). Central Pacific birds were more closely associated with specific CHL values while Eastern Pacific birds visited waters with specific SST values. In addition, Central
Pacific albatrosses frequented regions of high eddy kinetic energy during this period (Table 3 ).

Despite greater overlap between at-sea distribution during nonbreeding (Figure 2), the Central Pacific birds associated with SSTs characteristic of temperature fronts in the western North Pacific, while Eastern Pacific birds associated with SSHs of large eddies and fronts in the Central North Pacific (Table 3).

\section{Reproductive Metrics}

Population growth for Guadalupe differed significantly from Tern Island $\left(F_{3,23}=157, P<0.001\right)$ (Figure 7$)$. There was no significant population growth at Tern Island $(P=0.286$, $R^{2}=0.08$, slope $\left.=0.016\right)$, however during this same time the Eastern Pacific colony grew from 4 pairs to 457 pairs over 26 years $\left(P<0.001, R^{2}=0.87\right.$, slope $\left.=0.194\right)$. Combined data for major Central Pacific colonies (Midway, Kure, and French Frigate Shoals) show a stable population growth trend (pooled data: 1992-2005, $P=0.596, R^{2}=0.08$, slope $=0$ ) (Arata et al., 2009).

Breeding success was greater at the Eastern Pacific ( mean $=0.79$ chicks fledged $/$ egg, range $=0.69-0.87, n=5$ years $)$ compared to the Central Pacific colony (mean $=0.66$ chicks fledged/egg, range $=0.43-0.73, n=9$ years, Wilcoxon-Rank Sum $\mathrm{W}=44, P=0.005$ ) (Figure 8).

\section{DISCUSSION}

The results of our study show a clear delineation of foraging distribution and oceanic resource use between Laysan albatrosses from a former historic range contrasted by that of a recent range expansion. The oceanic conditions differ markedly in core areas when albatrosses are most constrained by breeding activities, but our results also demonstrate that overlap still occurs outside the breeding period when most individuals aggregate in the central North Pacific. Finally, our comparison of breeding performance between populations suggests that Laysan albatrosses benefited from range expansion to the Eastern Pacific where rapid population growth may be attributed to a combination of available nest sites and high biological productivity in the California Current System.

\section{Population-Level Differences in Foraging Distribution and Habitat Use}

Our results show fundamental differences in the distribution of albatrosses from both populations (Figure 2). For example, there is little overlap in foraging ranges when breeding but these differences become reduced after breeding when birds are no longer tied to a colony. A primary reason for these differences occurs because the Central Pacific populations breed in tropical/subtropical conditions. Therefore, individuals must commute northward to more productive regions along the North Pacific Transition Zone by exploiting faster wind speeds that were observed over the study period (Figures $\mathbf{3 A - C}, \mathbf{6}$ ). In contrast, the Eastern Pacific population at Guadalupe Island is situated within the productive California Current System, where food resources are closer to the colony. As such, we observed different foraging behavior where Guadalupe albatrosses remained closer to the 

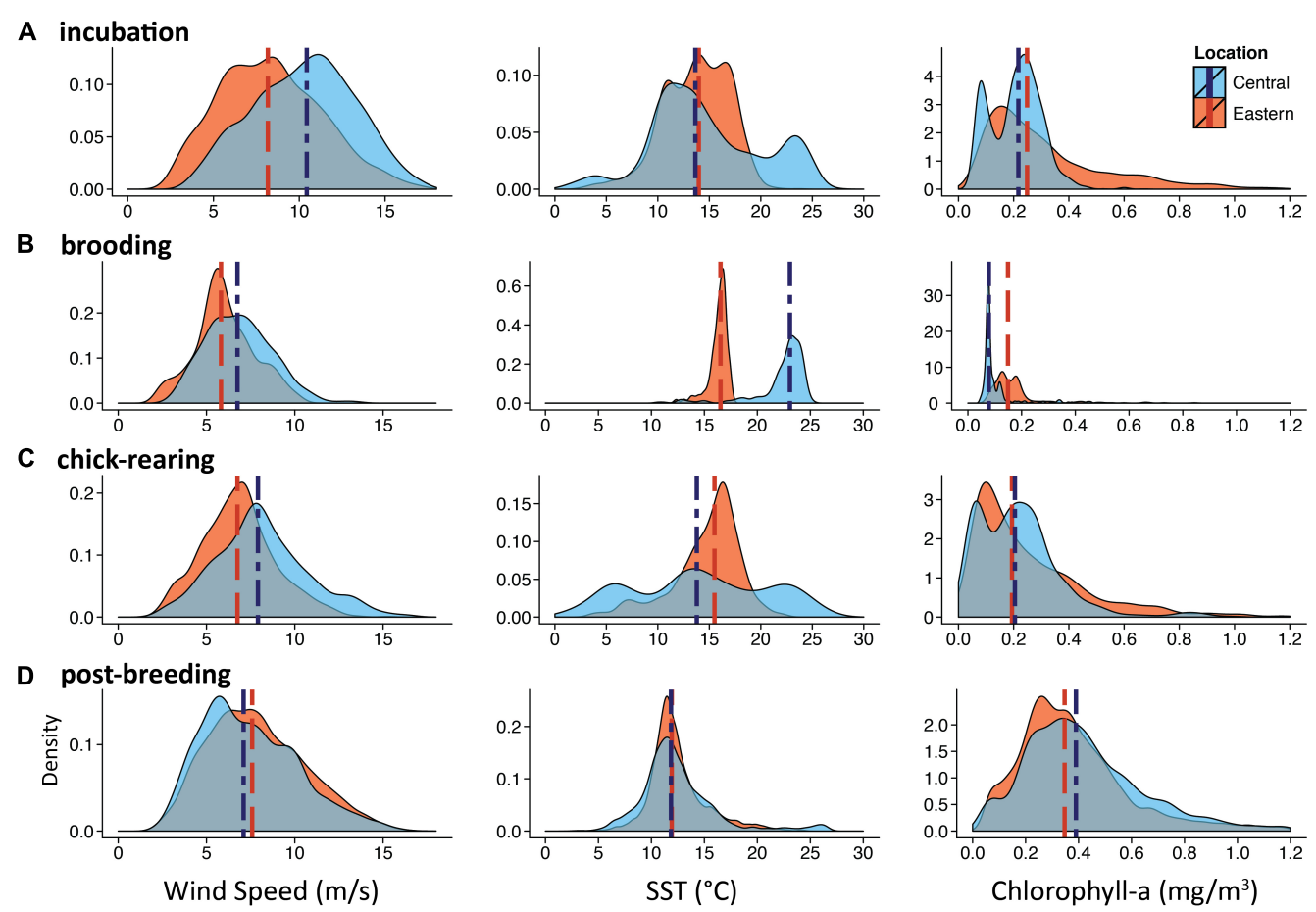

FIGURE 6 | Remotely sensed oceanographic data for at-sea locations. Density plots are of remotely sensed wind speed, sea surface temperature, and chlorophyll-a values from at-sea locations of tagged albatrosses during the incubation, brooding, chick-rearing, and post-breeding periods. Dashed lines represent median values. Blue D Central Pacific and Red D Eastern Pacific colonies.

colony, traveled shorter distances, had shorter trip durations, and spent more time on the water (Table 2), presumably feeding (Conners et al., 2015).

The profound difference in distribution between albatross populations resulted in the use of oceanic habitats that are influenced by markedly distinct physical processes (Figures 3-6). For example, the dominant oceanographic feature exploited by Central Pacific albatrosses was the North Pacific Current and associated North Pacific Transition Zone that forms large eddies and fronts (Polovina et al., 2001; Seki et al., 2004; Palacios et al., 2006; Kappes et al., 2010). Here, the Transition Zone Chlorophyll Front forms important albatross foraging grounds (Fernandez et al., 2001; Hyrenbach et al., 2002; Kappes et al., 2010, 2015). To access productive foraging areas Central Pacific birds utilize the Trades, Westerlies, and transient winter low-pressure systems to transit across oligotrophic subtropical waters (Fernandez et al., 2001; Kappes et al., 2015). Consequently, we observed that habitat use of Tern Island albatrosses was associated with CHL and wind speed and to a lesser extent EKE and SST (Table 3).

In contrast, the population breeding at Guadalupe Island in the Eastern Pacific foraged predominantly in the California Current System, among the most consistent and productive ocean systems on earth (Olson, 2002). Here, productivity is heavily influenced by wind-driven upwelling that is seasonally regenerated and characterized by strong cross-shore biological gradients (Bograd et al., 2004; Palacios et al., 2006; Checkley and Barth, 2009). Coastal wind stress from seasonal winter storms and spring northwesterly winds drive upwelling, establishing density fronts that form filaments and jets that propagate eddy kinetic energy and water masses offshore from spring to fall (Strub et al., 1997; Strub and James, 2000). These frontal features develop meanders and form closed eddies that persist into the following winter (Strub et al., 1987; Lynn et al., 2003). These factors concentrate and transport nutrients, primary production, and secondary production westward (Hickey and Banas, 2008), forming important foraging habitat for coastal and pelagic fish species and a suite of apex predators, including albatrosses (Laurs et al., 1984; Block et al., 2011; Childers et al., 2011; Reese et al., 2011). Here, we observed that habitat use of Guadalupe Island albatrosses was most strongly associated with SST.

Wind enables albatrosses to efficiently travel long distances (Warham, 1996). Wind speed data (Figure 6 and Table 4) support Central Pacific birds' utilization of the strong winter Westerly wind current maxima. Eastern Pacific birds experience reduced winds from transient eastward-moving winter polar low-pressure systems and less intense winter poleward winds of the California Current System (Longhurst, 1998). Later, during brooding and chick-rearing, Central Pacific wind speeds diminish as the frequency of winter low-pressure systems and intensity of the Westerlies decrease toward summer lows (Longhurst, 1998). At this same time, winds for East Pacific albatross also decrease but to a lesser extent because the strong equatorward winds that drive the California Current begin to ramp up 


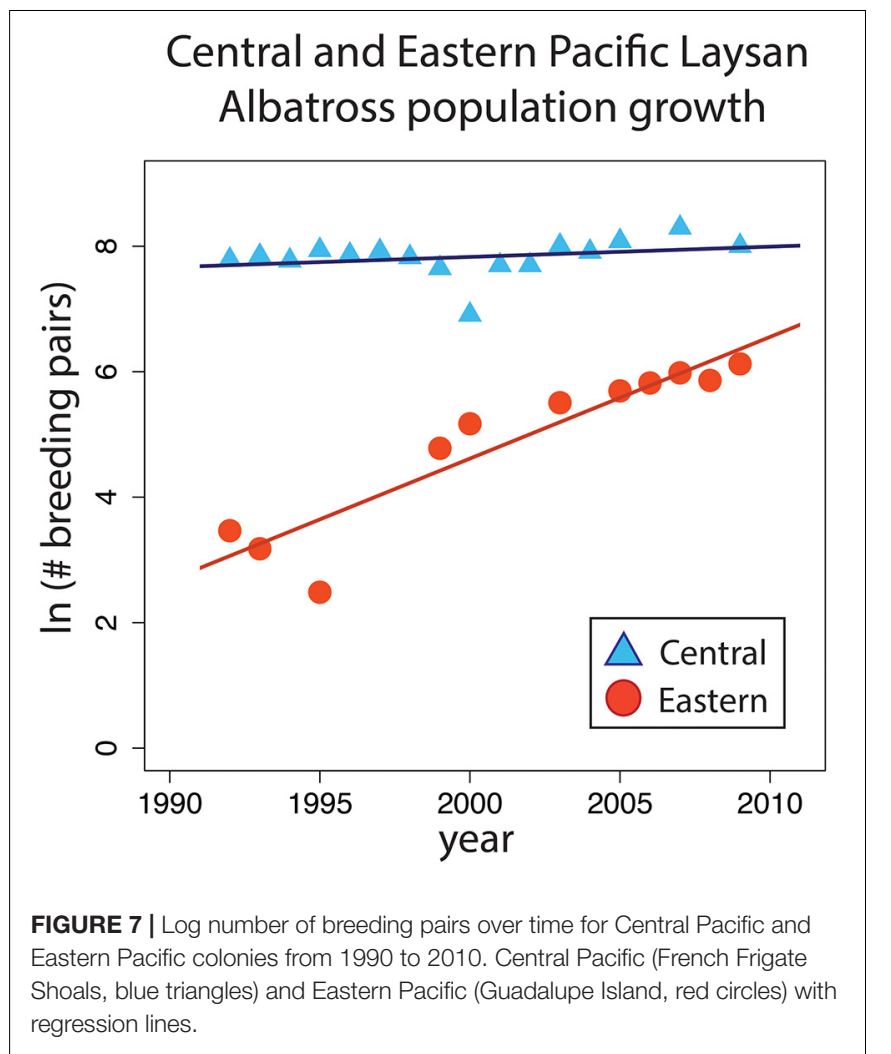

(Bograd et al., 2009). This late-season shift in wind patterns could disproportionately impact the mobility of Central Pacific birds, compromising their ability to provision older chicks late in the chick-rearing period.

Sea surface temperatures accessed by Eastern Pacific albatrosses during rearing may result from utilization of the Coastal Upwelling Front's offshore edge following the collapse of offshore jets and filaments during the California Current System spring transition. This phenomenon is supported by a reduction in mean distance to shore (483 $\mathrm{km}$ incubation to $283 \mathrm{~km}$ chickrearing) and consistent with the California Current core position as it moves closer to shore during the spring-summer (Bograd and Lynn, 2003). During this time the Central Pacific birds are visiting the cold side of the Transition Zone Chlorophyll Front. These observations suggest the birds have plasticity in the use of SST as a cue for foraging habitat.

Eastern Pacific birds accessed waters with a broad distribution of CHL values likely due to high variability in CHL productivity across eddies and jets of the California Current System (Thomas et al., 2001). These filament and jet features can have high CHL values that support large zooplankton volumes and aggregate biomass and higher trophic organisms such as fishes, seabirds and cetaceans (Hayward and Mantyla, 1990; Huntley et al., 1995; Sakuma and Ralston, 1997; Logerwell and Smith, 2001; Yen et al., 2006; Henson and Thomas, 2007; Wakefield et al., 2009, 2011; Tynan et al., 2005). Temporal and spatial lags between primary and secondary production in the California Current System can separate higher trophic organisms from phytoplankton (Smith and Lane, 1991), which may be responsible for the variance in CHL density plots. Access to these features that are located near breeding colonies is likely advantageous for Eastern Pacific albatrosses.

Despite minimal overlap when breeding, Laysan albatrosses from both populations overlapped to a greater extent $(>20 \%$ of the $50 \%$ UD) during the boreal summer/autumn when birds are recovering after breeding. Interestingly, both populations converged in the cooler pelagic waters of the subarctic gyre in the North Pacific (Figure 2D), an area characterized by Aleutian passes where strong currents mix Bering Sea waters with subarctic gyres and large numbers of albatrosses are known to aggregate (Suryan and Fischer, 2010). Differences in distribution during this period may be tied to different Western and Eastern North Pacific features, including the strong eddies and mesoscale energy of the Kuroshio Extension in the West compared to the large Haida-type eddies and the Gulf of Alaska in the East (Longhurst, 1998). Given that albatrosses from the Central Pacific exploit this region while breeding, their return to the colony to begin another breeding cycle is shorter in duration with more time in flight compared to albatrosses from the Eastern Pacific. Interestingly, while Guadalupe birds traveled greater distance from the colony, the overall distances traveled during postbreeding were not different between the populations. Albatrosses from Guadalupe Island may rely on specific wind features such as late fall cold fronts that move towards Western North America to make a rapid return to the colony from the post-breeding oceanic habitats.

\section{Drivers of Range Expansion}

Stable population numbers suggest that the Central Pacific albatross populations are near carrying capacity. While historical estimates of Laysan albatross population size are disputed, those for just one Central Pacific colony were reportedly as high as 2 million birds prior to feather hunting (Nutting, 1904), far exceeding current numbers. Although nest site availability may be limiting for Laysan albatrosses on some Central Pacific islands, it is not a major limiting factor for the size of the Eastern Pacific population (Arata et al., 2009). Laysan albatross have also likely experienced reduced inter-specific competition with sympatrically breeding species as population numbers for short-tailed and black-footed albatrosses have dramatically decreased during the 20th century (Hasegawa and Degange, 1982; Arata et al., 2009). This decline may have decreased competition at sea, increasing available foraging habitat for Laysan albatrosses, as suggested by their expansion into waters historically occupied by shorttailed albatrosses (Yesner, 1976). Range expansion into the Eastern Pacific may also entail a diet change, which warrants further research. Because Central Pacific populations of shorttailed albatrosses have not rebounded to historical levels despite reductions in intra- and inter-specific competition, it could be that conditions have changed at sea, altering the timing, availability, and access to prey. Laysan albatrosses may have capitalized on such changes in climatological factors and/or human impacts. 


\section{Number of chicks fledged per egg at Central and Eastern Pacific Laysan Albatross colonies}

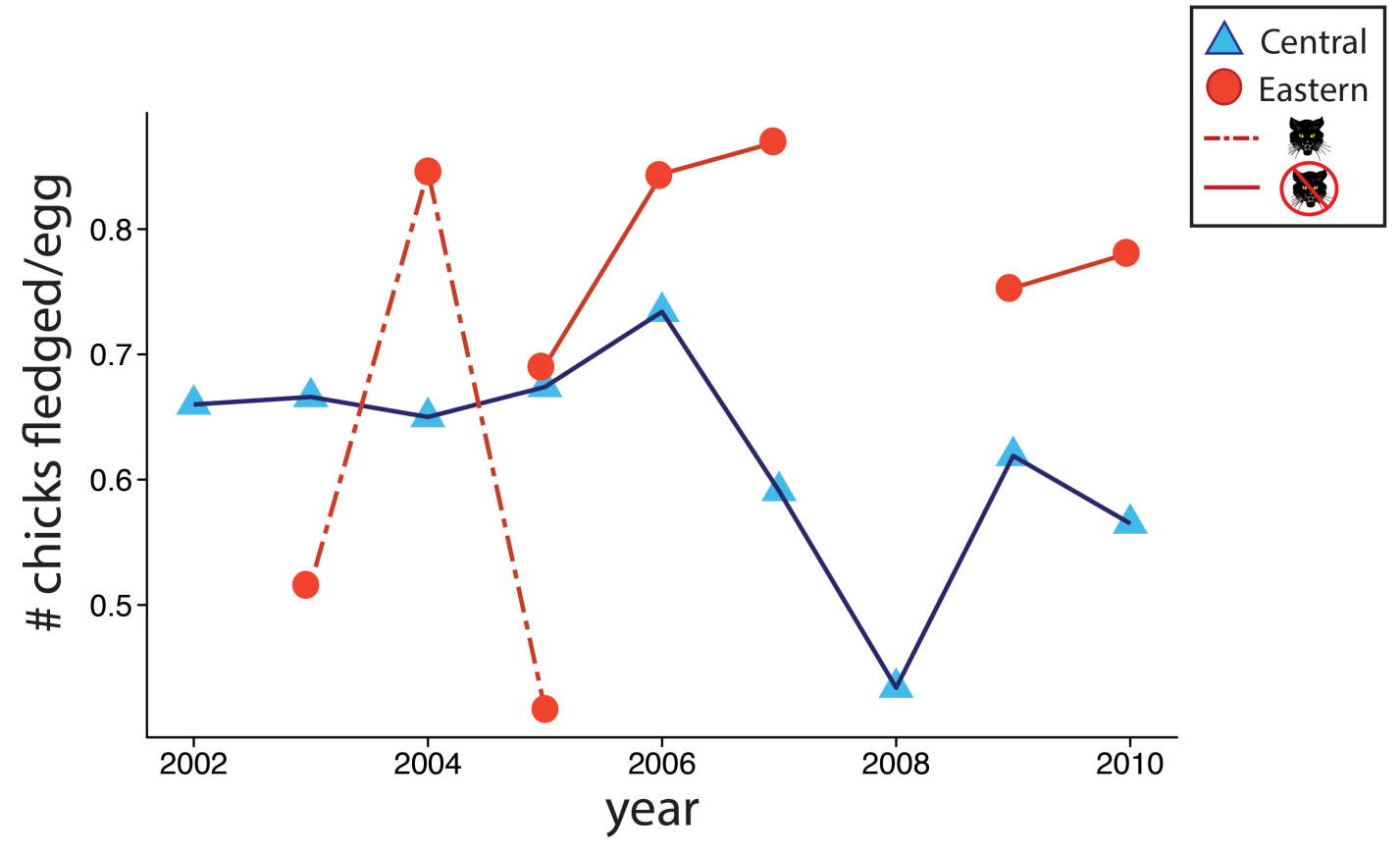

FIGURE 8 | Fledging success for Central Pacific and Eastern Pacific colonies from 2002 to 2010. Central Pacific (French Frigate Shoals, blue triangles) and Eastern Pacific (Guadalupe Island, red circles) colonies. The dashed line represents 2003-2005, when introduced cats impacted fledging success by predating on adult albatross, followed by "widow" years when albatrosses either did not breed or suffered lower reproductive success as they paired and bonded with new mate. Cat control began on Guadalupe in 2003, year 2005 shows fledgling success at sub colonies with and without introduced cats.

TABLE 4 | Mean and standard error values for oceanographic variables from at-sea locations of tagged albatrosses from Central Pacific and Eastern Pacific colonies during the incubation, brooding, chick-rearing, and post-breeding periods.

\begin{tabular}{|c|c|c|c|c|c|c|c|}
\hline & & Wind speed $(\mathrm{m} / \mathrm{s})$ & $\begin{array}{l}\text { Sea surface } \\
\text { temp }\left({ }^{\circ} \mathrm{C}\right)\end{array}$ & $\begin{array}{c}\text { Chlorophyll } \\
\left(\mathrm{mg} / \mathrm{m}^{3}\right) \times 10^{4}\end{array}$ & $\begin{array}{l}\text { Eddy kinetic } \\
\text { energy (J/kg) }\end{array}$ & $\begin{array}{l}\text { Ekman transport } \\
(\mathrm{m} / \mathrm{s}) \times 10^{7}\end{array}$ & $\begin{array}{c}\text { Sea surface } \\
\text { height }(\mathrm{m})\end{array}$ \\
\hline \multirow[t]{2}{*}{ Incubation } & Central & $10.3(0.06)$ & $14.7(0.11)$ & $0.21(0.002)$ & $14.23(0.43)$ & $-8.36(0.68)$ & $0.015(0.001)$ \\
\hline & Eastern & $8.3(0.07)$ & $13.7(0.07)$ & $0.32(0.005)$ & $8.56(0.27)$ & $-7.93(0.57)$ & $0.015(0.001)$ \\
\hline \multirow[t]{2}{*}{ Brooding } & Central & $6.8(0.11)$ & $22.3(0.15)$ & $0.1(0.004)$ & $18.97(1.32)$ & $-21.92(0.84)$ & $0.007(0.004)$ \\
\hline & Eastern & $6(0.1)$ & $16.3(0.05)$ & $0.17(0.006)$ & $11.87(0.62)$ & $-0.64(0.65)$ & $-0.021(0.002)$ \\
\hline \multirow[t]{2}{*}{ Chick-rearing } & Central & $8.1(0.1)$ & $14.1(0.24)$ & $0.2(0.006)$ & $12.09(0.72)$ & $-12.71(0.78)$ & $-0.014(0.002)$ \\
\hline & Eastern & $6.8(0.06)$ & $14.8(0.1)$ & $0.19(0.016)$ & $12.36(0)$ & $-0.32(0.6)$ & $-0.019(0.001)$ \\
\hline \multirow[t]{2}{*}{ Post-breeding } & Central & $7.5(0.04)$ & $12.5(0.05)$ & $0.46(0.005)$ & $8.12(0.15)$ & $-5.9(0.26)$ & $0.041(0.001)$ \\
\hline & Eastern & $7.9(0.02)$ & $12.5(0.02)$ & $0.41(0.003)$ & $5.89(0.07)$ & $-3.16(0.16)$ & $0.023(0.0004)$ \\
\hline
\end{tabular}

\section{Changes in the North Pacific Ocean and Range Expansion}

The phenology of albatross reproduction at both colonies coincide with those of large-scale seasonal oceanographic patterns. Both the southward migration of the Transition Zone Chlorophyll Front and the south to north renewal of coastal upwelling correspond with albatross hatch's onset (Bograd et al., 2004, 2009; Awkerman et al., 2008). This shift in productivity reduces foraging travel during hatching and brooding, a critical point in the albatross breeding cycle. This synchrony of breeding with predictable seasonal productivity and prey availability can be important to top consumers (Cushing, 1990; Sydeman and Bograd, 2009). The Pacific Decadal Oscillation shift of the late 1970s/early 1980s (Ebbesmeyer et al., 1991; Holt, 1996; McGowan et al., 1998; Mantua and Hare, 2002; Bograd and Lynn, 2003) coincided with the Laysan albatross colonization of the Eastern Pacific (Pitman, 1985; Dunlap, 1988). Climatic phenomena such as the deeper eastward shift of the Aleutian Low-pressure system accompanied by a southward shift in storm tracks likely influenced wind patterns (Trenberth and Hurrell, 1994) and may have contributed to colonization by this winddependent species. 
Several changes have occurred in the California Current System since the inception of the Eastern Pacific albatross colonies in the early 1980s, including a significant trend toward a longer upwelling season (Bograd et al., 2009), upper-ocean warming, increased stratification, decreased offshore seasonal signal (Bograd and Lynn, 2003), and increases in eddy kinetic energy in summer/fall (Stammer and Wunsch, 1999). The net effects of these changes on albatross habitat are unclear. Some changes, such as the recent shoaling of the hypoxic layer in the California Current System (Bograd et al., 2008; Howard et al., 2020), may enhance cephalopod habitat, a primary prey of the Eastern Pacific Laysan albatrosses (Pitman et al., 2004). Additionally, other surface-feeding seabird species with similar foraging techniques as Laysan albatrosses [blackfooted albatross, black-winged petrel (Pterodroma nigripennis), California gull (Larus californicus), northern fulmar (Fulmarus glacialis), pink-footed shearwater (Puffinus creatopus), western gull (Larus occidentalis), and wedge-tailed shearwater (Puffinus pacificus)] have also increased in the California Current System (Hyrenbach and Veit, 2003). Collectively, these large-scale spatiotemporal changes in oceanographic patterns and productivity in the North Pacific may have played a significant role in the initial colonization and subsequent persistence of the Eastern Pacific Laysan albatross colony. Additional effects brought on by global climate change may further influence the metapopulation structure of this species.

\section{Climate Change, Range Expansion, and the Metapopulation}

Climate change scenarios forecast increases in Central Pacific El Niño events (Yeh et al., 2009; Wang et al., 2019), which are associated with decreases in the southerly migration of the Transition Zone Chlorophyll Front (Polovina et al., 2001) and reduction of Central North Pacific prey fields (Chen et al., 2007; Tseng et al., 2011). Historically, El Niño events are followed by La Niña conditions when Central Pacific Laysan albatrosses experienced significant decreases in productivity (Dearborn et al., 2001; Seki et al., 2002; Kappes et al., 2010), which is linked to changes in wind fields that impact albatross mobility (Thorne et al., 2016). Furthermore, Bograd et al. (2004) found long-term changes in the timing of the southerly maximum of the Transition Zone Chlorophyll Front, a seasonal phenomenon important to the reproduction of Central Pacific albatrosses. Central Pacific birds may be increasingly competing for dwindling at-sea resources (Hazen et al., 2013). This scenario could be compounded by the impacts of sea-level rise in reducing breeding area on low-lying atolls (Baker et al., 2006; Webb and Kench, 2010; Reynolds et al., 2015), the core breeding habitat for Central Pacific populations.

The recently established Eastern Pacific colony on Guadalupe Island has high reproductive success and is growing rapidly (Figure 7). In addition to a location embedded in favorable foraging conditions, this colony is buffered from sea-level rise by elevated breeding sites, with thousands of hectares of nesting habitat. With low intra-specific competition at sea, it is improbable that density-dependent processes will soon regulate this Eastern Pacific population. We have observed young born in the Eastern Pacific return to breed. Central Pacific birds founded the Eastern Pacific colonies, and bidirectional visitations occur between these populations. During 8 years of observation, we observed 3 adults banded as chicks or loafers at the Central Pacific colonies breeding on Guadalupe. Researchers have sighted Guadalupe born birds at Central Pacific colonies (Lindsay Young, personal communication). These observations indicate that Eastern Pacific albatrosses interchange with the Central Pacific colonies and may play an important role in metapopulation dynamics under future climate change scenarios.

\section{Invasive Species}

While ample breeding habitat exists in the Eastern Pacific, introduced species such as feral cats (Felis domesticus) are present on many of these islands including Guadalupe. Cats prey on seabirds (Medina et al., 2011), and, in years when Guadalupe albatrosses were exposed to introduced cat predation, productivity decreased (Figure 8). This illustrates the impact that introduced species can have on nascent seabird populations and underscores the role of invasive species eradications in supporting seabird (meta)populations.

\section{CONCLUSION}

In summary, Laysan albatrosses recently expanded their range from colonies on small low-lying subtropical atolls where birds make long foraging commutes to large tall volcanic islands in the Eastern Pacific embedded within a highly productive eastern boundary current. During the breeding period, this expansion has resulted in: (a) low spatial overlap, (b) access to novel oceanographic habitats, and (c) differential utilization of oceanic habitats/features. Birds from the new colony have reduced ranges, foraging trip lengths and duration, and spend more time on the water. These factors undoubtedly contribute to the observed higher reproductive output and population growth rate for the Eastern Pacific colony. Immigration of Central Pacificborn birds may also play a role in these patterns. The range expansion did not impact the post-breeding period as heavily where birds largely utilized habitats with similar environmental variables. Climate change (oceanographic processes and sealevel change) may reinforce this range expansion. In seabirds, the degree to which range expansion will synergize with exposure to other threats on land (e.g., predators and habitat degradation) and at sea (e.g., contaminants and fisheries interactions) is largely unknown. This phenomenon has the potential to dramatically alter static management strategies and warrants further study.

Species are increasingly adjusting their ranges in response to rapidly changing environments. This will inevitably result in novel distributions and changes of the "realized" within the "fundamental" niche (Hutchinson, 1957). The differences we found in model ranking of environmental variables between populations cautions against using predictive habitat modeling based on current populations, as results may not be transferrable under different environmental conditions (e.g., 
oceanographic systems), particularly for highly mobile species with relatively broad diets. It is important to recognize the destination habitats that receive immigrants are rapidly changing as well. For example, Bograd et al. (2009) suggested recent changes in the phenology of upwelling in the California Current System may spawn greater mismatches in predator needs and prey availability. Perhaps the Laysan albatrosses, buffered by plasticity in their opportunistic palate, ability to move large distances, and lack of intraspecific competition in the Eastern Pacific, are well positioned to capitalize on this change.

\section{DATA AVAILABILITY STATEMENT}

The datasets presented in this study can be found in online repositories. The names of the repository/repositories and accession number(s) can be found below: http:// www.seabirdtracking.org, searchable by species, location, or investigator. All data analysis codes are available by reasonable request to the lead author.

\section{ETHICS STATEMENT}

The animal study was reviewed and approved by Institutional Animal Care \& Use Committee, University of California, Santa Cruz.

\section{AUTHOR CONTRIBUTIONS}

$\mathrm{RH}$ and SS designed the experiment, collected, analyzed, interpreted the data, and wrote the manuscript. MA collected, analyzed, and interpreted the data. MF-L collected the data. DF collected and interpreted the data. $\mathrm{EH}$ and $\mathrm{YT}$ analyzed and interpreted data. DPC designed the experiment and provided the tags. BT designed the experiment and wrote the manuscript. DAC designed the experiment, interpreted the data, and wrote the manuscript. All authors contributed to the article and approved the submitted version.

\section{FUNDING}

This research was part of the Tagging of Pacific Predators (TOPP) program, funded in part by the National Ocean Partnership Program (N00014-02-1-1012), the Office of Naval Research (N00014-00-1-0880 and N00014-03-1-0651), the Gordon and

\section{REFERENCES}

Ainely, D. G., and Divoky, G. J. (2001). Seabird Responses to Climate Change. San Diego, CA: Academic Press.

Arata, J. A., Sievert, P. R., and Naughton, M. B. (2009). Status assessment of Laysan and black-footed albatrosses, North Pacific Ocean, 19232005. Scientific Investigations Report 2009-5131. Available online at: https://doi.org/10.3133/sir20095131. (accessed September 30, 2020).
Betty Moore, David and Lucille Packard, and Alfred P. Sloan Foundations. RH was supported by a US Environmental Protection Agency Greater Research Opportunity Fellowship (MA-916588). Additional funding provided by the: Frank M. Chapman Memorial Fund, American Museum of Natural History, Friends of Long Marine Lab, Will J. Reid Foundation, Dr. Earl H. Myers and Ethel M. Myers Oceanographic and Marine Biology Trust, National Marine Fisheries Service Office of International Affairs, Island Conservation, and Grupo de Ecología y Conservación de Islas.

\section{ACKNOWLEDGMENTS}

We thank Alfonso Aquirre Muñoz, Ikerne Aguirre Muñoz, Dan Barton, José M. Barredo Barberena, Allison B. Birkhead, Melinda Conners, Travis Cooper, Anna Cummings, Elizabeth Flint, Irene Espinosa, Ricardo González Gómez, Mario Alberto Guerrero Madriles, Savannah and Esmé Henry, M. Ángel Hermosillo Bueno, Julio C. Hernández Montoya, Brad Keitt, Caitlin LeeRodney, Kristen Lindquist, Alejandro Manríquez Ayub, Virginia McDermott, Luciana Luna Mendoza, Diane R. Menuz, Charles Moore (Alguita Foundation), Gaby Calli Ramírez de Arellano, Marlenne Rodríguez Malagón, Araceli Samiago Herrera, Jose Angel Sanchez-Pacheco, Scott Seganti, Jonathon Steinberg, Noé Silva Estudillo, Flor M. Torres García, Shaye Wolf, Grupo de Ecología y Conservación de Islas, Island Conservation, Secretaría de Marina - Armada de México, Sociedad Cooperativa de Producción Pesquera de Participación Estatal Abuloneros y Langosteros, and U.S. Fish and Wildlife Service for assistance with field work and logistics. Steven Bograd, Dan Malone, Pete Raimondi, Daniel Palacios, Patrick Robinson, Tim Tinker, and Andreas Walli provided assistance with data analyses and interpretation. James A. Estes and Paul L. Koch helped immensely with critical review and helpful insights. We also thank the Comisión Nacional de Áreas Naturales Protegidas, Hawaiian Islands National Wildlife Refuge, U.S. Fish and Wildlife Service, and Department of the Interior for permission to conduct research on Guadalupe and Tern Islands. Conservación de Islas and the U.S. Fish and Wildlife Service also provided banding data. Alan Swithenbank and Steve Teo provided the SST correction algorithm for light-based GLS data. All protocols employed in this study were approved by the Institutional Animal Care and Use Committees at UCSC. This research was conducted under all necessary international, federal, state, and institutional wildlife permits.

Awkerman, J. A., Anderson, D. J., and Whittow, G. C. (2008). "Laysan albatross (Phoebastria immutabilis)," in The Birds of North America, ed. A. Poole (Ithaca, NY: Cornell Lab of Ornithology).

Baker, J. D., Littnan, C. L., and Johnston, D. W. (2006). Potential effects of sealevel rise on the terrestrial habitats of endangered and endemic megafauna in the Northwestern Hawaiian Islands. Endangered Species Res. 4, 1-10. doi: 10.1515/9780824846268-003

BirdLife International (2021). Species Factsheet: Phoebastria immutabilis. Available online at: http://www.birdlife.org (accessed October 05, 2021). 
Block, B. A. I, Jonsen, D., Jorgensen, S. J., Winship, A. J., Shaffer, S. A., Bograd, S. J., et al. (2011). Tracking apex marine predator movements in a dynamic ocean. Nature 475, 86-90. doi: 10.1038/nature10082

Bograd, S. J., Castro, C. G., Di Lorenzo, E., Palacios, D. M., Bailey, H., Gilly, W., et al. (2008). Oxygen declines and the shoaling of the hypoxic boundary in the California Current. Geophys. Res. Lett. 35, 1-6.

Bograd, S. J., Foley, D. G., Schwing, F. B., Wilson, C., Laurs, R. M., Polovina, J. J., et al. (2004). On the seasonal and interannual migrations of the transition zone chlorophyll front. Geophys. Res. Lett. 31, 1-5. doi: 10.1029/2004GL020637

Bograd, S. J., and Lynn, R. J. (2003). Long-term variability in the Southern California Current System. Deep-Sea Res. Part II-Topical Stud. Oceanogr. 50, 2355-2370. doi: 10.1016/s0967-0645(03)00131-0

Bograd, S. J., Schroeder, I., Sarkar, N., Qiu, X. M., Sydeman, W. J., and Schwing, F. B. (2009). Phenology of coastal upwelling in the California Current. Geophys. Res. Lett. 36, 1-5.

Brink, K. H., and Cowles, T. J. (1991). The coastal transition zone program. J. Geophys. Res.-Oceans 96, 14637-14647. doi: 10.1029/91jc01206

Brothers, N. P., Cooper, J., and Lokkeborg, S. (1999). The Incidental Catch of Seabirds by Longline Fisheries: Worldwide Review and Technical Guidelines for Mitigation. FAO Fisheries Circular No. 937. Rome: FAO.

Castelao, R. M., Mavor, T. P., Barth, J. A., and Breaker, L. C. (2006). Sea surface temperature fronts in the California Current System from geostationary satellite observations. J. Geophys. Res.-Oceans 111, 1-13.

Chan, F. T., Stanislawczyk, K., Sneekes, A. C., Dvoretsky, A., Gollasch, S., Minchin, D., et al. (2019). Climate change opens new frontiers for marine species in the Arctic: current trends and future invasion risks. Global Change Biol. 25, 25-38. doi: $10.1111 /$ gcb.14469

Checkley, D., and Barth, J. (2009). Patterns and processes in the California Current System. Prog. Oceanogr. 83, 49-64. doi: 10.1016/j.pocean.2009.07.028

Chen, I.-C., Hill, J. K., Ohlemuller, R., Roy, D. B., and Thomas, C. D. (2011). Rapid range shifts of species associated with high levels of climate warming. Science 333:3.

Chen, X. J., Zhao, X. H., and Chen, Y. (2007). Influence of El Nino/La Nina on the wester winter-spring cohort of neon flying squid (Ommastrephes bartramii) in the northwestern Pacific Ocean. ICES J. Mar. Sci. 64, 1152-1160. doi: 10.1093/ icesjms/fsm 103

Chiba, H., Kawakami, K., Suzuki, H., and Horikoshi, K. (2007). The distribution of seabirds in the Bonin Islands, Southern Japan. J. Yamashina Institute Ornithol. 39, 1-17. doi: 10.3312/jyio.39.1

Childers, J., Snyder, S., and Kohin, S. (2011). Migration and behavior of juvenile North Pacific albacore (Thunnus alalunga). Fisheries Oceanogr. 20, 157-173. doi: 10.1111/j.1365-2419.2011.00575.x

Conners, M., Hazen, E., Costa, D., and Shaffer, S. (2015). Shadowed by scale: subtle behavioral niche partitioning in two sympatric, tropical breeding albatross species. Mov. Ecol. 3:28. doi: 10.1186/s40462-015-0060-7

Cushing, D. H. (1990). Plankton production and year-class strength in fish populations - an update in the match mismatch hypothesis. Adv. Mar. Biol. 26, 249-293. doi: 10.1016/s0065-2881(08)60202-3

Dearborn, D. C., Anders, A. D., and Flint, E. N. (2001). Trends in reproductive success of Hawaiian seabirds: is guild membership a good criterion for choosing indicator species? Biol. Conserv. 101, 97-103. doi: 10.1016/s0006-3207(01) 00030- 1

Doney, S. C., Ruckelshaus, M., Duffy, J. E., Barry, J. P., Chan, F., English, C. A., et al. (2011). Climate change impacts on marine ecosystems. Annu. Rev. Mar. Sci. 4, $11-37$.

Dunlap, E. (1988). Laysan Albatross nesting on Guadalupe Island. Mexico. American Birds 42, 180-181.

Ebbesmeyer, C. C., Cayan, D. R., McLain, D. R., Nichols, F. H., Peterson, D. H., and Redmond, K. T. (1991). "1976 step in Pacific climate: forty environmental changes between 1968-1975 and 1977-1984," in Proceedings of the Seventh Annual Pacific Climate (PA- CLIM) Workshop, April 1990, eds J. L. Betancourt and V. L. Sharp (California, CA: California Department of Water Resources).

Elith, J., Kearney, M., and Phillips, S. (2010). The art of modelling rangeshifting species. Methods Ecol. Evol. 1, 330-342. doi: 10.1111/j.2041-210x.2010. 00036.x

Elith, J., Phillips, S. J., Hastie, T., Dudik, M., Chee, Y. E., and Yates, C. J. (2011). A statistical explanation of MaxEnt for ecologists. Diversity Distributions 17, 43-57. doi: $10.1111 / \mathrm{j} .1472-4642.2010 .00725 . \mathrm{x}$
Fernandez, P., Anderson, D. J., Sievert, P. R., and Huyvaert, K. (2001). Foraging destinations of three low-latitude albatross (Phoebastria) species. J. Zool. 254, 391-404. doi: 10.1017/s0952836901000899

Finkelstein, M., Keitt, B. S., Croll, D. A., Tershy, B., Jarman, W. M., RodriguezPastor, S., et al. (2006). Albatross species demonstrate regional differences in North Pacific marine contamination. Ecol. Appl. 16, 678-686. doi: 10.1890/ 1051-0761(2006)016[0678:asdrdi]2.0.co;2

Finkelstein, M. E., Gwiazda, R. H., and Smith, D. R. (2003). Lead poisoning of seabirds: environmental risks from leaded paint at a decommissioned military base. Environ. Sci. Technol. 37, 3256-3260. doi: 10.1021/es026272e

Furness, R. W. (2003). Impacts of fisheries on seabird communities. Scientia Marina 67, 33-45. doi: 10.3989/scimar.2003.67s233

Furness, R. W., and Camphuysen, C. J. (1997). Seabirds as monitors of the marine environment. ICES J. Mar. Sci. 54, 726-737. doi: 10.1006/jmsc.1997.0243

Gallo-Reynoso, J. P., and Figuero-Carranza, A. L. (1996). The breeding colony of Laysan albatrosses on Isla de Guadalupe, Mexico. West. Birds 27, 70-76.

Gaston, A. J. (2004). Seabirds: A Natural History. New Haven: Yale University Press. Gremillet, D., and Boulinier, T. (2009). Spatial ecology and conservation of seabirds facing global climate change: a review. Mar. Ecol.-Prog. Series 391, 121-137. doi: $10.3354 /$ meps08212

Hasegawa, H., and Degange, A. R. (1982). The short-tailed albatross Diomedea albatrus its status distribution and natural history. Am. Birds 36, 806-814.

Hayward, T. L., and Mantyla, A. W. (1990). Physical, chemical and biological structure of a coastal eddy near Cape Mendocino. J. Mar. Res. 48, 825-850. doi: $10.1357 / 002224090784988683$

Hazen, E. L., Jorgensen, S., Rykaczewski, R. R., Bograd, S. J., Foley, D. G., Jonsen, I. D., et al. (2013). Predicted habitat shifts of Pacific top predators in a changing climate. Nat. Clim. Change 3, 234-238. doi: 10.1038/nclimate1686

Henry, R. W. (2011). Consequences of Range Expansion in Laysan Albatrosses. Santa Cruz, CA: University of California.

Henson, S. A., and Thomas, A. C. (2007). Phytoplankton scales of variability in the California Current System: 1. Interannual and cross-shelf variability. J. Geophys. Res.-Oceans 112, 1-12.

Hernández Montoya, J. C., Juárez-Rodríguez, M., Méndez-Sánchez, F., Aguirre-Muñoz, A., Rojas-Mayoral, E., Íñigo-Elías, E., et al. (2019). Sexual dimorphism and foraging trips of the laysan albatross (Phoebastria immutabilis) on Guadalupe Island. Animals 9:364. doi: 10.3390/ani90 60364

Hernández Montoya, J. C., Luna-Mendoza, L., Aguirre-Muñoz, A., MéndezSánchez, F., Félix-Lizárraga, M., and Barredo-Barberena, J. M. (2014). Laysan Albatross on Guadalupe Island, México: current status and conservation actions. Monogr. West. N. Am. Nat. 7, 543-557. doi: 10.3398/042.007.0101

Hickey, B. M., and Banas, N. S. (2008). Why is the northern end of the California current system so productive? Oceanography 21, 90-107. doi: 10.5670/oceanog. 2008.07

Hitch, A. T., and Leberg, P. L. (2007). Breeding distributions of north American bird species moving north as a result of climate change. Conserv. Biol. 21, 534-539. doi: 10.1111/j.1523-1739.2006.00609.x

Holt, R. D. (1996). Food Webs in Space: An Island Biogeographic Perspective. Berlin: Springer, 313-323.

Howard, E. M., Penn, J. L., Frenzel, H., Seibel, B. A., Bianchi, D., Renault, L., et al. (2020). Climate-driven aerobic habitat loss in the California current system. Sci. Adv. 2020:eaay3188. doi: 10.1126/sciadv.aay3188

Howell, S. N., and Webb, S. W. (1990). The seabirds of Las Revillagigedo, Mexico. Wilson Bull. 102, 140-146.

Howell, S. N. G., and Webb, S. W. (1992). Changing status of the Laysan Albatross in Mexico. Am. Birds 46, 220-223.

Hughes, L. (2000). Biological consequences of global warming: is the signal already apparent? Trends Ecol. Evol. 15, 56-61. doi: 10.1016/s0169-5347(99)01764-4

Huntley, M. E., Zhou, M., and Nordhausen, W. (1995). Mesoscale distribution of zooplankton in the California Current in late spring, observed by optical plankton counter. J. Mar. Res. 53, 647-674. doi: 10.1357/00222409532 13061

Hutchinson, G. E. (1957). Population studies - animal ecology and demography - concluding remarks. Cold Spring Harbor Symposia Quantitative Biol. 22, $415-427$.

Huyer, A. (1983). Coastal upwelling in the California Current System. Prog. Oceanogr. 12, 259-284. doi: 10.1016/0079-6611(83)90010-1 
Hyrenbach, K. D., Fernandez, P., and Anderson, D. J. (2002). Oceanographic habitats of two sympatric North Pacific albatrosses during the breeding season. Mar. Ecol.-Prog. Series 233, 283-301. doi: 10.3354/meps 233283

Hyrenbach, K. D., and Veit, R. R. (2003). Ocean warming and seabird communities of the southern California Current System (1987-98): response at multiple temporal scales. Deep-Sea Res. Part II-Topical Stud. Oceanogr. 50, 2537-2565. doi: 10.1016/s0967-0645(03)00123-1

Jones, H. P., Tershy, B. R., Zavaleta, E. S., Croll, D. A., Keitt, B. S., Finkelstein, M. E., et al. (2008). Severity of the effects of invasive rats on seabirds: a global review. Conserv. Biol. 22, 16-26. doi: 10.1111/j.1523-1739.2007.00859.x

Kappes, M. A., Shaffer, S. A., and Tremblay, Y. (2015). Reproductive constraints influence habitat accessibility, segregation, and preference of sympatric albatross species. Mov. Ecol. 3:34. doi: 10.1186/s40462-0150063-4

Kappes, M. A., Shaffer, S. A., Tremblay, Y., Foley, D. G., Palacios, D. M., Robinson, P. W., et al. (2010). Hawaiian albatrosses track interannual variability of marine habitats in the North Pacific. Prog. Oceanogr. 86, 246-260. doi: 10.1016/j. pocean.2010.04.012

Kavelaars, M. M., Baert, J. M., Stienen, E. W. M., Shamoun-Baranes, J., Lens, L., and Müller, W. (2020). Breeding habitat loss reveals limited foraging flexibility and increases foraging effort in a colonial breeding seabird. Mov. Ecol. 8: 45 . doi: 10.1186/s40462-020-00231-9

Lambrinos, J. G. (2004). How interactions between ecology and evolution influence contemporary invasion dynamics. Ecology 85, 2061-2070. doi: 10.1890/038013

Laurs, R. M., Fiedler, P. C., and Montgomery, D. R. (1984). Albacore tuna catch distributions relative to environmental features observed from satellites. DeepSea Res. Part a-Oceanogr. Res. Papers 31, 1085-1099. doi: 10.1016/01980149(84)90014- 1

Logerwell, E. A., and Smith, P. E. (2001). Mesoscale eddies and survival of late stage Pacific sardine (Sardinops sagax) larvae. Fisheries Oceanogr. 10, 13-25. doi: 10.1046/j.1365-2419.2001.00152.x

Longhurst, A. R. (1998). Ecological Geography of the Sea. San Diego, CA: Academic Press.

Lynn, R. J., Bograd, S. J., Chereskin, T. K., and Huyer, A. (2003). Seasonal renewal of the California Current: the spring transition off California. J. Geophys. Res.-Oceans 108, 1-11. (accessed May 10, 2021).

Mantua, N. J., and Hare, S. R. (2002). The Pacific decadal oscillation. J. Oceanogr. $58,35-44$.

Maxwell, S. M., Hazen, E. L., Bograd, S., Halpern, B. S., Breed, G., Nickel, B., et al. (2013). Cumulative impacts on marine predators. Nat. Commun. 4:2688. doi: $10.1038 /$ ncomms 3688

McGowan, J. A., Cayan, D. R., and Dorman, L. M. (1998). Climate-ocean variability and ecosystem response in the northeast Pacific. Science 281, 210-217. doi: 10.1126/science.281.5374.210

Medina, F. M., Bonnaud, E., Vidal, E., Tershy, B. R., Zavaleta, E. S., Donlan, C. J., et al. (2011). A global review of the impacts of invasive cats on island endangered vertebrates. Global Change Biol. 17, 3503-3510. doi: 10.1111/j. 1365-2486.2011.02464.x

Meldgaard, M. (1988). The Great Auk, Pinguinus impennis (L.) in Greenland. Historical Biol. 1, 145-178. doi: 10.1080/08912968809386472

Naughton, M. B., Romano, M. D., and Zimmerman, T. S. (2007). A Conservation Action Plan for the Black-footed Albatross (Phoebastria nigripes) and Laysan Albatross (P. immutabilis), Ver 1.0. Page 40 USFWS Report. Available online at: https://www.fws.gov/pacific/migratorybirds/pdf/Albatross $\% 20$ Action $\%$ 20Plan\%20ver.1.0.pdf (accessed May 10, 2021).

Nutting, C. C. (1904). The bird rookeries on the island of Laysan. Popular Sci. Monthly 63, 321-332.

Olson, D. B. (2002). Biophysical Dynamics of Ocean Fronts. New York, NY: John Wiley \& Sons.

Palacios, D. M., Bograd, S. J., Foley, D. G., and Schwing, F. B. (2006). Oceanographic characteristics of biological hot spots in the North Pacific: a remote sensing perspective. Deep-Sea Res. Part II-Topical Stud. Oceanogr. 53, 250-269. doi: 10.1016/j.dsr2.2006.03.004

Phillips, S. J., Anderson, R. P., and Schapire, R. E. (2006). Maximum entropy modeling of species geographic distributions. Ecol. Modell. 190, 231-259. doi: 10.1016/j.ecolmodel.2005.03.026
Pitman, R. L. (1985). The marine birds of Alijos Rocks. Mexico. West. Birds 16, 81-92.

Pitman, R. L. (1988). Laysan Albatross breeding in the eastern Pacific-and a comment. Pac. Seabird Grp. Bull. 15:52.

Pitman, R. L., and Ballance, L. T. (2002). The changing status of marine birds breeding at San Benedicto Island, Mexico. Wilson Bull. 114, 11-19. doi: 10 . 1676/0043-5643(2002)114[0011:tcsomb]2.0.co;2

Pitman, R. L., Walker, W. A., Everett, W. T., and Gallo-Reynoso, J. P. (2004). Population Status, foods and foraging of Laysan Albatrosses Phoebastria immutabilis nesting on Guadalupe Island, Mexico. Mar. Ornithol. 32, $159-165$.

Polovina, J. J., Howell, E., Kobayashi, D. R., and Seki, M. P. (2001). The transition zone chlorophyll front, a dynamic global feature defining migration and forage habitat for marine resources. Prog. Oceanogr. 49, 469-483. doi: 10.1016/s00796611(01)00036-2

R Development Core Team (2010). "R: A language and environment for statistical computing," in R Foundation for Statistical Computing, ed. R. D. C. Team (Vienna: R Development Core Team).

Reese, D. C., O’Malley, R. T., Brodeur, R. D., and Churnside, J. H. (2011). Epipelagic fish distributions in relation to thermal fronts in a coastal upwelling system using high-resolution remote-sensing techniques. ICES J. Mar. Sci. 68, 1865-1874. doi: 10.1093/icesjms/fsr107

Reynolds, M. H., Courtot, K. N., Berkowitz, P., Storlazzi, C. D., Moore, J., and Flint, E. (2015). Will the effects of sea-level rise create ecological traps for Pacific Island Seabirds? PLoS One 10:e0136773. doi: 10.1371/journal.pone.0136773

Rice, D. W., and Kenyon, K. W. (1962). Breeding distribution, history and populations of North Pacific albatrosses. Auk 79, 365-386. doi: 10.2307/ 4082822

Sakuma, K. M., and Ralston, S. (1997). Vertical and horizontal distribution of juvenile Pacific whiting (Merluccius productus) in relation to hydrography off California. California Cooperative Oceanic Fisheries Investigations Reports 38, 137-146.

Seki, M. P., Flint, E. N., Howell, E., Ichii, T., Polovina, J. J., and Yatsu, A. (2004). Transition Zone. North Saanich: North Pacific Marine Science Organization.

Seki, M. P., Polovina, J. J., Kobayashi, D. R., Bidigare, R. R., and Mitchum, G. T. (2002). An oceanographic characterization of swordfish (Xiphias gladius) longline fishing grounds in the springtime subtropical North Pacific. Fisheries Oceanogr. 11, 251-266. doi: 10.1046/j.1365-2419.2002.00207.x

Shaffer, S. A., Tremblay, Y., Awkerman, J. A., Henry, R. W., Teo, S. L. H., Anderson, D. J., et al. (2005). Comparison of light- and SST-based geolocation with satellite telemetry in free-ranging albatrosses. Mar. Biol. 147, 833-843. doi: 10.1007/ s00227-005-1631-8

Shaffer, S. A., Tremblay, Y., Weimerskirch, H., Scott, D., Thompson, D. R., Sagar, P. M., et al. (2006). Migratory shearwaters integrate oceanic resources across the Pacific Ocean in an endless summer. Proc. Natl. Acad. Sci. USA 103, 12799-12802. doi: 10.1073/pnas.0603715103

Smith, S. L., and Lane, P. V. Z. (1991). The jet off Point Arena, California - its role in aspects of secondary production in the copepod Eucalnus-Californicus Johnson. J. Geophys. Res.-Oceans 96, 14849-14858. doi: 10.1029/91jc00906

Stammer, D., and Wunsch, C. (1999). Temporal changes in eddy energy of the oceans. Deep-Sea Res. Part II-Topical Stud. Oceanogr. 46, 77-108. doi: 10.1016/ s0967-0645(98)00106-4

Strub, P. T., Allen, J. S., Huyer, A., Smith, R. L., and Beardsley, R. C. (1987). Seasonal cycles of currents, temperatures, winds, and sea-level over the Northeast Pacific Continental-Shelf - 35-Degrees-N to 48-Degrees-N. J. Geophys. Res.-Oceans 92, 1507-1526. doi: 10.1029/jc092ic02p01507

Strub, P. T., Chereskin, T. K., Niiler, P. P., James, C., and Levine, M. D. (1997). Altimeter-derived variability of surface velocities in the California Current System .1. Evaluation of TOPEX altimeter velocity resolution. J. Geophys. Res.-Oceans 102, 12727-12748. doi: 10.1029/97jc00448

Strub, P. T., and James, C. (2000). Altimeter-derived variability of surface velocities in the California Current System: 2. Seasonal circulation and eddy statistics. Deep-Sea Res. Part II-Topical Stud. Oceanogr. 47, 831-870. doi: 10.1016/s09670645(99)00129-0

Strub, P. T., Kosro, P. M., and Huyer, A. (1991). The nature of the cold filaments in the California Current System. J. Geophys. Res.-Oceans 96, 14743-14768. doi: $10.1029 / 91$ jc01024 
Suryan, R. M., and Fischer, K. N. (2010). Stable isotope analysis and satellite tracking reveal interspecific resource partitioning of nonbreeding albatrosses off Alaska. Can. J. Zool.-Revue Canadienne Zoologie 88, 299-305. doi: 10.1139/ z10-002

Suryan, R. M., Sato, F., Balogh, G. R., Hyrenbach, K. D., Sievert, P. R., and Ozaki, K. (2006). Foraging destinations and marine habitat use of short-tailed albatrosses: a multi-scale approach using first-passage time analysis. Deep-Sea Res. Part II-Topical Stud. Oceanogr. 53, 370-386. doi: 10.1016/j.dsr2.2006.01.012

Sydeman, W. J., and Bograd, S. J. (2009). Marine ecosystems, climate and phenology: introduction. Mar. Ecol. Prog. Series 393, 185-188. doi: 10.3354/ meps08382

Thomas, A. C., Carr, M. E., and Strub, P. T. (2001). Chlorophyll variability in eastern boundary currents. Geophys. Res. Lett. 28, 3421-3424. doi: 10.1029/ 2001 gl013368

Thomas, C. D., Franco, A. M. A., and Hill, J. K. (2006). Range retractions and extinction in the face of climate warming. Trends Ecol. Evol. 21, 415-416. doi: 10.1016/j.tree.2006.05.012

Thomas, C. D., and Lennon, J. J. (1999). Birds extend their ranges northwards. Nature 399, 213-213. doi: 10.1038/20335

Thorne, L. H., Conners, M. G., Hazen, E. L., Bograd, S. J., Antolos, M., Costa, D. P., et al. (2016). Effects of El Niño-driven changes in wind patterns on North Pacific albatrosses. J. R. Soc. Interface 13:20160196. doi: 10.1098/rsif.2016.0196

Tremblay, Y., Shaffer, S. A., Fowler, S. L., Kuhn, C. E., McDonald, B. I., Weise, M. J., et al. (2006). Interpolation of animal tracking data in a fluid environment. J. Exp. Biol. 209, 128-140. doi: 10.1242/jeb.01970

Trenberth, K. E., and Hurrell, J. W. (1994). Decadal atmosphere-ocean variations in the Pacific. Clim. Dynamics 9, 303-319. doi: 10.1007/s003820050027

Tseng, C. T., Sun, C. L., Yeh, S. Z., Chen, S. C., Su, W. C., and Liu, D. C. (2011). Influence of climate-driven sea surface temperature increase on potential habitats of the Pacific saury (Cololabis saira). ICES J. Mar. Sci. 68, 1105-1113. doi: 10.1093/icesjms/fsr070

Tynan, C. T., Ainley, D. G., Barth, J. A., Cowles, T. J., Pierce, S. D., and Spear, L. B. (2005). Cetacean distributions relative to ocean processes in the northern California Current System. Deep-Sea Res. Part II-Topical Stud. Oceanogr. 52, 145-167. doi: 10.1016/j.dsr2.2004.09.024

Vitousek, P. M., Mooney, H. A., Lubchenco, J., and Melillo, J. M. (1997). Human domination of Earth's ecosystems. Science 277, 494-499. doi: 10.1126/science. 277.5325.494

Wakefield, E. D., Phillips, R. A., and Matthiopoulos, J. (2009). Quantifying habitat use and preferences of pelagic seabirds using individual movement data: a review. Mar. Ecol.-Prog. Series 391, 165-182. doi: 10.3354/meps08203

Wakefield, E. D., Phillips, R. A., Trathan, P. N., Arata, J., Gales, R., Huin, N., et al. (2011). Habitat preference, accessibility, and competition limit the global distribution of breeding Black-browed Albatrosses. Ecol. Monogr. 81, 141-167. doi: 10.1890/09-0763.1

Walther, G. R., Post, E., Convey, P., Menzel, A., Parmesan, C., Beebee, T. J. C., et al. (2002). Ecological responses to recent climate change. Nature 416, 389-395.

Wang, B., Luo, X., Yang, Y. M., Sun, W., Cane, M. A., Cai, W., et al. (2019). Historical change of El Niño properties sheds light on future changes of extreme El Niño. Proc. Natl. Acad. Sci. U.S.A. 116, 22512-22517. doi: 10.1073/pnas. 1911130116
Warham, J. (1990). The Petrels: Their Ecology and Breeding Systems. London: Academic Press.

Warham, J. (1996). The Behaviour, Population Biology and Physiology of the Petrels. Cambridge: Academic Press.

Waugh, S. M., Weimerskirch, H., Cherel, Y., Shankar, U., Prince, P. A., and Sagar, P. M. (1999). Exploitation of the marine environment by two sympatric albatrosses in the Pacific Southern Ocean. Mar. Ecol.-Prog. Series 177, 243-254. doi: 10.3354/meps177243

Webb, A. P., and Kench, P. S. (2010). The dynamic response of reef islands to sealevel rise: evidence from multi-decadal analysis of island change in the Central Pacific. Glob. Planetary Change 72, 234-246. doi: 10.1016/j.gloplacha.2010.05. 003

Wolf, S. G., Sydeman, W. J., Hipfner, J. M., Abraham, C. L., Tershy, B. R., and Croll, D. A. (2009). Range-wide reproductive consequences of ocean climate variability for the seabird Cassin's Auklet. Ecology 90, 742-753. doi: 10.1890/ 07-1267.1

Worton, B. J. (1989). Kernel methods for estimating the utilization distribution in home-range studies. Ecology 70, 164-168. doi: 10.2307/1938423

Wren, J., Shaffer, S., and Polovina, J. (2019). Variations in black-footed albatross sightings in a North Pacific transitional area due to changes in fleet dynamics and oceanography 2006-2017. Deep Sea Res. Part II: Topical Stud. Oceanogr. 16:104605. doi: 10.1016/j.dsr2.2019.06.013

Wynn, R. B., Josey, S. A., Martin, A. P., Johns, D. G., and Yesou, P. (2007). Climatedriven range expansion of a critically endangered top predator in northeast Atlantic waters. Biol. Lett. 3, 529-532. doi: 10.1098/rsbl.2007.0162

Yeh, S. W., Kug, J. S., Dewitte, B., Kwon, M. H., Kirtman, B. P., and Jin, F. F. (2009). El Nino in a changing climate. Nature 461, U511-U570.

Yen, P. P. W., Sydeman, W. J., Bograd, S. J., and Hyrenbach, K. D. (2006). Springtime distributions of migratory marine birds in the southern California Current: oceanic eddy associations and coastal habitat hotspots over 17 years. DeepSea Res. Part II-Topical Stud. Oceanogr. 53, 399-418. doi: 10.1016/j.dsr2.2006. 01.013

Yesner, D. R. (1976). Aleutian-Island albatrosses - population history. Auk 93, 263-280.

Young, L. (2010). Inferring colonization history and dispersal patterns of a longlived seabird by combining genetic and empirical data. J. Zool. 281, 232-240. doi: 10.1111/j.1469-7998.2010.00698.x

Young, L., Vanderwerf, E., Smith, D., Polhemus, J., Swenson, N., Swenson, C., et al. (2009). Demography and natural history of Laysan Albatross on Oahu, Hawaii. Wilson J. Ornithol. 121, 722-729. doi: 10.1676/08-150.1

Conflict of Interest: The authors declare that the research was conducted in the absence of any commercial or financial relationships that could be construed as a potential conflict of interest.

Copyright (C) 2021 Henry, Shaffer, Antolos, Félix-Lizárraga, Foley, Hazen, Tremblay, Costa, Tershy and Croll. This is an open-access article distributed under the terms of the Creative Commons Attribution License (CC BY). The use, distribution or reproduction in other forums is permitted, provided the original author(s) and the copyright owner(s) are credited and that the original publication in this journal is cited, in accordance with accepted academic practice. No use, distribution or reproduction is permitted which does not comply with these terms. 